\title{
Market liquidity risks of foreign exchange derivatives and cross-country equity portfolio allocations
}

\begin{abstract}
Foreign exchange derivatives (FXD) are important tools for hedging foreign exchange (FX) risks and enhancing returns of international portfolios. However, the ability to use FXD can be constrained by higher trading costs and the liquidity risks of the FXD available in different markets/currencies across countries. In this study, we investigate whether the wide cross-sectional and temporal variations observed in the liquidity level of FXD markets are associated with the cross-country allocation decisions of foreign portfolio investors. Using an extensive dataset of 40 countries and a number of alternative specifications, our study finds that investors tend to allocate more wealth in countries which provide liquid and cost-effective opportunities for using FXD. Our results suggest that regulatory reforms aimed at developing FXD markets could be a potential policy measure for attracting higher levels of foreign equity portfolio investments.
\end{abstract}

JEL classification: G11; G15

Keywords: Foreign equity portfolio allocations; foreign exchange derivatives; market liquidity risks 


\section{Introduction}

Although international portfolio investment diversifies country-specific risks to a considerable extent, it also exposes investors to foreign exchange (FX) risks (see Eun and Resnick, 1988, 1994; Glen and Jorion, 1993; Jorion, 1993). Within the standard framework of international portfolio allocations, Fidora et al. (2007) provide strong evidence that equity portfolio investors face real FX risks when investing abroad. ${ }^{1}$ Drawing on the framework of asset pricing models, a number of studies also show that international portfolio investors require a material FX risk premium at the market level (Carrieri et al, 2006; De Santis and Gerard, 1998; Dumas and Solnik, 1995).

In terms of managing FX risk, studies on theoretical portfolio optimization show that hedging FX risk improves the risk-return profile of international portfolios relative to an unhedged portfolio (see Eun and Resnick, 1988; Jorion, 1993). Further, Duffie et al. (2010) suggest that if used responsibly, foreign exchange derivatives (FXD) provide important risk management and liquidity benefits to the financial system as well as nonfinancial corporations and other market participants. Using a sample of the U.S. investors, Perold and Schulman (1988) empirically demonstrate that FX hedging reduces risk. Such practices of hedging FX risks are also extensively followed by professional investors. ${ }^{2}$

Studies also demonstrate that FXD are utilized to enhance returns. For example, Cao et al. (2011) demonstrate that international mutual funds are significant users of FXD, and such funds display higher risk-adjusted returns than other funds. In addition to hedging FX

\footnotetext{
${ }^{1}$ Column 5 of Table 1 (discussed in detail under section 3.1) shows the country-specific standard deviations of real effective FX rates. In the absence of FX risk, provided purchasing power parity (PPP) holds, these figures for all countries should be zero. However, as seen from the positive figures, the FX rate significantly deviates from PPP and poses material real FX risks for international investors.

${ }^{2}$ From a practitioner's point of view, Macquarie's Walter Scott Global Equity Fund (Hedged), an Australian domiciled fund, reports the following use of FX risk hedging to its investors in the product disclosure statement: "In addition to gaining exposure to Walter Scott's investment process via the underlying fund, Macquarie aims to substantially hedge the fund's exposure to international assets back to Australian dollars. As a result, your exposure to currency fluctuation and the risk of decline in the Australian dollar value of the fund's investments due to these fluctuations will be reduced when compared to an un-hedged strategy otherwise making the same investment" (see www.macquarie.com.au/dafiles/Internet/mgl/au/docs$\mathrm{pa} / \mathrm{pds} /$ walter-scott-global-equity-fund-hedged.pdf, pp.5).
} 
risks and return enhancing motives, Cao et al. (2010) also note two other alternative motives for using FXD by fund managers. The first is insurance against extreme events, particularly the abrupt fall in asset prices during periods of financial crises and the second is to try and maximise their own performance to meet market expectations.

The evidence in the literature and professional practice clearly supports the view that foreign portfolio investors make extensive use of FXD for various purposes. However, Culp and Mackay (1994) note that institutions/investors face market liquidity risks ${ }^{3}$, among others, in the trading of FXD. Similarly, Duffie et al. (2010) also show that rapid reduction in market liquidity is one of the major risks in FXD markets. Based on the findings of a survey of FXD usage by US non-financial firms, Bodnar et al. (1996) further demonstrate that transaction $\operatorname{costs}^{4}$ (dealer fees) and market liquidity risk associated with usage of FXD generates high levels of constraints for the users of FXD. Liquidity risks of FXD are even more concerning for the comparatively thinly traded and informationally more opaque emerging markets' currencies. ${ }^{5}$ For example, Henderson (2002) show that relative to FXD trading in developed markets, liquidity level in emerging markets is much lower, implying higher transaction costs. Madura and Fox (2011) show that the bid-ask spread on forward contract transactions are much higher on currencies from emerging markets. Bekaert and Hodrick (2012) also note that the most liquid currencies (those typically trading at a spread of less than 10 pips) are the "G10" currencies ${ }^{6}$ with currencies from the emerging markets trading at significantly higher spreads. ${ }^{7}$

\footnotetext{
${ }^{3}$ They define market liquidity risk as the risk that a large trading might have an adverse impact on its market price and/or an abrupt movement in price or volatility may render it difficult to hedge or unwind a losing position, including a derivative position. As such, a sharp market movement may compel investors to initiate new positions or replace defaulted contracts, both of which may be complicated by high market liquidity risks, i.e. by adverse liquidity shocks.

${ }^{4}$ Liquidity level is shown to be inversely related to transaction costs as high trading costs cause investors to trade less (see Bekaert et al., 2007; Levine and Zervos, 1998a,b).

5 Duffie et al. (2010) recommend that increased market transparency to the investors enhances pricediscovery function of FXD markets, improving the provision of liquidity to hedgers.

${ }^{6} \mathrm{GBP}$, USD, EUR AUD, JPY, CHF, CAD, NZD, SEK and NOK.

${ }^{7}$ See Table 1 for further evidence from the dataset used in this study.
} 
Given the role of FXD in international portfolio investments and heterogeneous level of market liquidity/trading costs across different FXD markets, our study examines whether differences in market liquidity risks/trading costs of FXD are associated with the cross-country allocation decisions of international portfolio investors. Following Cooper and Kaplanis (1986), ${ }^{8}$ the framework of ICAPM suggests that higher liquidity risks and trading costs generate higher magnitude of deadweight costs, which reduce portfolio returns. As such, we hypothesize that countries/currencies with highly liquid and costeffective FXD markets attract higher levels of foreign equity portfolio allocations.

Incorporating two different types of unique and comprehensive FX liquidity dataset of 40 host countries (developed and emerging) our paper reports two important findings. First, the univariate analysis indicates significant cross-sectional variations in the liquidity levels of different FXD markets/currencies. The results also confirm that compared to their developed counterparts, the majority of emerging markets/currencies, which attract relatively lower share of foreign equity portfolio investments, also have smaller and illiquid FXD markets with comparatively higher costs of hedging FX risks. Evidence also suggests that FX risks in emerging markets are materially higher than developed markets, which further implies that the necessity of hedging FX risks is more prominent for emerging markets' currencies. $^{9}$

Second, our regression analysis shows that portfolio investors tend to allocate more wealth in the equities of those countries/currencies which exhibit highly liquid and costeffective FXD markets. Our results are robust to different specifications addressing omitted variable bias, reverse causality, market free float, effects of major financial centres and the use of alternative proxies of FXD market liquidity. Therefore for the first time this study provides evidence that the liquidity risks/trading costs of using FXD are important

\footnotetext{
${ }^{8}$ Discussed in section 2.

9 The figures in column 6 of Table 1 demonstrate that compared to developed markets, emerging markets' currencies are more volatile and pose significant real FX rate risks.
} 
determinants in the cross-country portfolio allocations of foreign investors. Therefore we suggest that reforms aimed at increasing the depth and breadth of FXD markets could have significant positive implications for attracting higher levels of foreign portfolio investments, particularly for emerging markets.

This paper makes three important contributions to the literature. First, although hedging in international investments is pervasive in practice, the relation between hedging FX risks and international portfolio diversification, to the best of our knowledge, has so far not been investigated in the literature. Most of the existing studies on the role of FXD in international portfolios focus on optimization models (see Eun and Resnick, 1988, 1994; Glen and Jorion, 1993; Jorion, 1989). This study empirically models cross-country allocations against the potential costs/liquidity of trading FXD across different markets/currencies in a robust theoretical framework.

Second, the literature on the implications of hedging FX risks has primarily focussed on non-financial firms and suggests that FX hedging reduces the volatility of cash flows, offers tax benefits, enhances market value and lowers interest rates (see Bartram et al., 2009; Campello et al., 2011; Chong et al, 2014; Zhou and Wang, 2013). We extend this area of literature by demonstrating the implications of liquidity risks/trading costs of using FXD on the cross-country allocation decisions of financial firms, i.e. by international equity portfolio investors.

Third, unlike other studies on international portfolio investments which focus primarily on the US and other developed markets (see Chan et al., 2005 for discussion), this study includes 61 source and 40 host countries (developed and emerging markets) covering a temporal span of 13 years (2001-2013). ${ }^{10}$ Contrary to the cross-sectional estimations used by existing studies (see Chan et al., 2005; Fidora et al., 2007), the wide

\footnotetext{
10 The turnover measure is only used for five year period (2001, 2004, 2007, 2010 and 2013).
} 
cross-sectional and temporal variations in our dataset allows us to use panel data models. ${ }^{11}$ We use the generalized least square (GLS) random effect panel data model ${ }^{12}$ but at the same time control for all observable time-varying variables, and unobservable country and time-specific effects by including country and time dummies. ${ }^{13}$

The rest of the paper is structured as follows. Section 2 describes the theoretical framework and the data used in the study. Section 3 provides the empirical analysis. Section 4 provides a brief conclusion.

\section{ICAPM framework and data}

We begin this section by briefly describing the theoretical framework followed by the description of the dataset we use in our study.

\subsection{Theoretical framework}

We use the ICAPM based equilibrium framework of Cooper and Kaplanis (1986) for our empirical analysis. In this section we briefly describe this framework. If the ICAPM holds in its pristine form then the following relation should hold in terms of investors investing in foreign markets:

$$
w_{i j t}=M_{j t}
$$

where $w_{i j t}$ is the equity portfolio country allocation of investors domiciled in country $i$ into foreign country $j$ for the time period $t$ and is defined as:

\footnotetext{
${ }^{11}$ Compared to the purely cross-sectional, studies show the use of panel data accords several advantages. For example, Baltagi (2008) shows that relative to pure cross-section or time series, panel data suffer less from multi-collinearity issues, produce more reliable and efficient estimates, and provide internal instrumental factors.

${ }^{12}$ We are unable to use the time-demeaned fixed effect model as two of our variables, i.e. bilateral distance and common language dummies, are time invariant.

13 The use of the random effect panel data model, along with country and time dummies, is the most conservative combination of panel data estimations benefiting from higher efficiency of GLS random effects (using within and between variations in the dataset) and greater robustness for controlling the country and time effects.
} 


$$
w_{i j t}=\frac{F P H_{i j t}}{\sum_{j=1}^{n} F P H_{i j t}}, \quad i \neq j
$$

where $F P H_{i j t}$ is the foreign portfolio holdings of investors in country $i$ of the securities issued by corporations of country $j^{14}(j=1$ to $n)$ for the time period $t . M_{j t}$ in Equation 1 is the ICAPM benchmark allocation for country $j$ for the time $t$ and is defined as:

$$
M_{j t}=\frac{M C_{j t}}{\sum_{j=1}^{n} M C_{j t}}
$$

where $M C_{j t}$ is the market capitalization of country $j$ for the time $t$. Incorporating the costs/risks of investing in foreign markets and in its simplest form, Cooper and Kaplanis's (1986) framework implies the following relation:

$$
w_{i j t}=M_{j t}-\frac{P_{i t} c_{i j t}}{h s^{2}}
$$

where $P_{i t}$ is the proportion of world wealth owned by investors of country $i$ for the time period $t . c_{i j t}$ is the potential risks/costs borne by investors domiciled in country $i$ for investing in the equities issued in country $j$ for the period $t . s^{2}$ is the constant variance of the portfolio's return and $h$ represents the Lagrange multiplier of the objective function maximizing investors' returns with constraints of $w_{i}^{\prime} I=1$ and the given constant variance. $^{15}$

Equation 4 implies that if foreign investors do not face any risk/cost, i.e. $c_{i j t}$ is zero, then they all must hold the world market portfolio, i.e. $w_{i j t}=M_{j t}$. However, on the other hand as the risk/cost $\left(c_{i j t}\right)$ for investing in a particular foreign country increases, investors deviate from the suggestion of the ICAPM in their cross-country allocations. In this study we represent liquidity risk and/or trading costs of FXD as one of the deadweight costs

\footnotetext{
${ }^{14}$ Since foreign exchange risk is only associated with investments in a foreign country $j$, we need to include the term $i \neq j$.

${ }^{15} I$ is a unity column vector.
} 
$\left(c_{i j t}\right)$ of investing in foreign markets. We aim to explain whether the cross-sectional and temporal variation in the liquidity risks/trading costs $\left(c_{i j t}\right)$ of FXD across different markets affect the foreign cross-country allocation decisions $\left(w_{i j t}\right)$ of portfolio investors. Our discussion, in section 1, of the possible implications, suggests that higher trading activities in a particular foreign market, i.e. proxy of lower liquidity risks and lower transaction costs $\left(c_{i j t}\right)$, should be positively associated with higher allocations $\left(w_{i j t}\right)$.

\subsection{Data}

We use the foreign equity portfolio holdings data of the Co-ordinated Portfolio Investment Survey (CPIS) of the International Monetary Fund (IMF) to construct the foreign equity allocation measure $\left(w_{i j t}\right)$. For the measure of the degree of cross-country FXD transaction costs and the liquidity risks we use two different sources of data. First, we employ the Triennial Central Bank Survey (TCBS) of the Bank of International Settlements (BIS) FXD turnover dataset. The second data is the Thompson Reuters' one-year forward bidask foreign exchange rate against US dollar. The data are described below.

\subsubsection{Measure of international portfolio allocation}

As defined by Equation 1, we need an estimate of bilateral portfolio allocation $\left(w_{i j t}\right.$, Equation 4) and the proxy of liquidity risks/trading costs of FXD markets $\left(c_{i j t}\right.$, Equation 4). Following Equation 2 we use the cross-country bilateral equity portfolio holding figure of the IMF's CPIS. ${ }^{16}$ The number of source countries (i.e. $i_{s}$ ) we use in our study is 61 and the number of host countries (i.e. $j_{s}$ ) is $40 .{ }^{17}$ Although we use an extensive set of countries, which includes developed and emerging markets, the choice of 40 host countries is

\footnotetext{
${ }^{16}$ For a detailed description of the data, refer to Fidora et al. (2007).

${ }^{17}$ See appendix for the list of source and host countries and also the emerging and developed markets.
} 
dictated by the availability of data on FXD liquidity figures and the other control variables we use. ${ }^{18}$

\subsubsection{Measures of FXD liquidity and transaction costs}

To capture the varying degree of FX derivative liquidity we employ three different measures. The first two proxies are volume based reflecting the turnover of the market. The third measure is a direct transaction cost measure reflecting the bid-ask spreads of one year forward market of buying a unit US dollar.

In the well-established literature of market microstructure, turnover in financial assets, i.e. measure of liquidity level, is shown to be inversely related to transaction costs as high trading costs cause investors to trade less (see Bekaert et al., 2007; Levine and Zervos, 1998a,b). As such, to measure the relative liquidity risks/trading costs of different FXD markets we use the FXD trading figures of the BIS as reported in their 2013 TCBS report. TCBS offers a unique and comprehensive report of OTC FX and FXD trading throughout the world at high levels of granularity and activity. It reports the average daily turnover figures (during the month of April) for the years 2001, 2004, 2007, 2010 and 2013. TCBS (2013, page 17) reports that turnover data provides a measure of market activity, and acts as a proxy for market liquidity. TCBS (2013) define turnover as the gross value of all deals entered into during a given period, and is measured in terms of the nominal or notional amount of the contracts. The data are collected over a one-month period, i.e. during the month of April, to mitigate the possibility of short-term variations in trading activity that may contaminate the data. For the purpose of cross-country comparison, the daily turnover averages are computed by scaling aggregate monthly turnover figure for the country in

\footnotetext{
18 CPIS reports the world total for assets and liabilities of source and host countries respectively, which includes data held by international organisations and other confidential investors. The share of the source countries included in our study is $97 \%$ of the total assets and the share of host countries is $93 \%$.
} 
question by the number of days in April on which the FX and FXD markets in that country are open. ${ }^{19}$

As noted above, since higher turnover is directly related to higher liquidity/lower trading costs, ${ }^{20}$ we construct two distinct volume based proxies of FXD turnover reflecting the country level liquidity/trading costs of different FXD markets across the globe. We denote the first variable as $F X D L B_{j t}$ (location based FXD turnover) which is the share of each country's trading activities in the location (country) based global turnover figures reported by the BIS:

$$
F X D L B_{j t}=\frac{F X D L B_{j t}}{\sum_{j=1}^{n} F X D L B_{j t}}
$$

The latter figure of $F X D L B_{j t}$ for each country $(j)$ and each year $(t)$ is computed by aggregating the daily average turnover values ${ }^{21}$ of outright forward contracts, FX swaps, currency swaps and options (reported in the BIS's 2013 website in Tables 21, 22, 23 and 24 respectively). ${ }^{22}$

The second relative volume measure is denoted as $F X D C B_{j t}$ (Currency based FXD turnover) and is constructed by the share of each currency ${ }^{23}$ in the global turnover values as shown below:

$$
F X D C B_{j t}=\frac{F X D C B_{j t}}{\sum_{j=1}^{n} F X D C B_{j t}}
$$

\footnotetext{
19 The BIS volume data for a particular currency/country is reported against all the other pair currencies reported by BIS in their Triennial Survey Report. However, when reported, they are all reported in the common USD currency. The 2013 BIS report (page 9) notes: "Non-US dollar legs of foreign currency transactions were converted into original currency amounts at average exchange rates for April of each survey year and then reconverted into US dollar amounts at average April 2013 exchange rates."

${ }^{20}$ Mihaljek and Packer (2010) empirically demonstrate that FXD turnover is positively related to equity market turnover (proxy of liquidity/transaction costs).

${ }^{21}$ The BIS adjusts the figure for local inter-dealer double-counting (i.e. figures reported on a "net-gross" basis).

${ }^{22}$ Obtained from the TCBS (2013), http://www.bis.org/publ/rpfx13.htm.

${ }^{23}$ Except for the Euro, we link each currency with its respective country from the available data.
} 
The latter measure of relative share is based on total FX turnover value by currency trading figures (reported in the BIS's 2013 website in Tables 25). As the BIS does not segregate the spot and FXD transactions for each currency, the relative share figures are based on total FX turnover, including spot transactions. However, following the aggregated figures (by instruments) shown in Table 1 of the BIS's 2013 TCBS report (see page 9), the five year total share of FXD in the total FX turnover is approximately $63 \%$. Clearly, $F X D C B_{j t}$ significantly captures the activities of FXD market activities. ${ }^{24}$

The two volume based measures are only available for five year period and could constrain the sample representation. Further, the literature notes that volume related proxies of liquidity may not be strongly correlated with other proxies (Goyenko et al., 2009). ${ }^{25}$ Therefore following Banti and Phylaktis (2015) we use a third measure of liquidity focusing on transaction costs, i.e. the bid-ask spread on forward contract. For each of the associated currencies in our sample we obtained the daily bid and ask one year forward rates of transacting a unit US dollar. This data, obtained from Thomson Reuters Datastream, is reported from five different sources (Barclays Bank Plc, WM/Reuters, Thomson Reuters, Tullett Prebon and National Bank of Switzerland). For each day we compute the bid-ask spread based $\left(F X D S B_{j t}\right)$ measure by scaling the difference between ask and bid rate by the mid-rate as shown in equation 7 .

$$
F X D S B_{j t}=\frac{A s k_{j t}-B i d_{j t}}{M i d_{j t}}
$$

\footnotetext{
${ }^{24}$ However, we do address the potential bias it may introduce in our estimations by including the share of the spot in all our regressions. The spot share data is reported in Table 20 of TCBS (2013) from web link: http://www.bis.org/publ/rpfx13.htm

${ }^{25} \mathrm{We}$ thank the anonymous reviewer for highlighting this issue and suggesting the alternative measure.
} 
The daily percentage spread is then average for each day from the five different sources and further averaged over the respective year.

\subsubsection{Control factors}

Following the empirical and theoretical suggestions in the literature we control for a number of factors which could potentially explain the variations in foreign portfolio allocations. For the ICAPM benchmark, as shown in Equation 3, we use the total market capitalization figures for each country obtained from the World Development Indicator (WDI) of the World Bank.

The most consistent and widely agreed factors proposed by the literature (see Fidora et al., 2007; Portes and Rey, 2005) are the bilateral familiarity or information flow variables reflecting the potential information acquisition costs of investing in foreign markets. Motivated by the use of gravity models used in the studies of international trade in securities (Portes and Rey, 2005), we control for the bilateral familiarity factor using three variables. First, we include a language dummy (Language) which takes the value of one if the pair-country shares a common language (official and widely spoken). Similarly, we also include the distance (Bilateral distance) between the capital cities of the pair countries. ${ }^{26}$ Chan et al. (2005) show that investors are more willing to hold stocks of those foreign companies whose products are familiar to them. As such, we further add the proportionate bilateral trade (Bilateral trade) factor obtained from the 'Bilateral Trade Statistics' of the IMF. For a pair-country, it is constructed by adding the value of the paircountry's total exports and imports with the resultant figure scaled by the source country's total trade with all foreign countries. All the bilateral familiarity proxies predict the probability of information flow, reflecting the degree of potential barriers foreign investors encounter when seeking information overseas (see Chan et al., 2005; Fidora et al., 2007).

\footnotetext{
${ }^{26}$ Both variables are obtained from www.nber.org/ wei/data.html (see Subramanian and Wei, 2007).
} 
We further incorporate the Capital control factor of the 'Economic Freedom Network', which ranges from 0 to 10 , with 0 reflecting completely closed markets and 10 indicating fully open markets for foreign investments. Since it is a time varying measure, it also accounts for any time effect in the financial liberalisation/integration process (see de Jong and de Roon, 2005). We get this data from the 'free the world' website (http://www.freetheworld.com). Next, we use the ratio of stock market capitalization to GDP as a measure of Stock market development/size obtained from the WDI of the World Bank. It captures the development level (visibility and depth) and size of the stock market, reflecting the significance of the capital market in the economy. We also include the turnover ratio reflecting dual measure of stock market liquidity and transaction costs. The turnover ratio is also obtained from the WDI of the World Bank and is constructed by taking the ratio of total equity traded to year end market capitalization.

We also incorporate the International Country Risk Guide's (ICRG) broad measures of forward looking country-specific economic policy risk measures. The Macroeconomic policy risk factor we use reflects the potential forward looking economic policy risk of investing in a particular foreign market. Economic policy risk is measured on a scale of 050 points, denoting five potential sources of economic risk (GDP per head, real GDP growth, inflation rate, budget balance as a percentage of GDP and current account as a percentage of GDP). ${ }^{27}$ As a measure of investor protection (Investor protection) and following La Porta et al. (1998), we use the ICRG's law and order sub-component of country risk rating ranging from 0 to 6 , with 6 indicating potentially the lowest risk in terms of formulating the quality of legal rules and their observance.

To control for the effect of risk diversification potential, we further include the correlation coefficients (Diversification potential) between the pair-country equity returns

\footnotetext{
${ }^{27}$ For detailed descriptions of the ratings, refer to the ICRG's methodology documentation on their website (http://www.prsgroup.com/ICRG_Methodology.aspx).
} 
constructed using the country level daily total return index of MSCI. We also include a three year moving average return (Momentum) to capture the likelihood that foreign investors could favour countries with higher historical returns, referred to as return chasing or feedback hypothesis (see Bohn and Tesar, 1996; Richards, 2005). Furthermore, we use the three year moving standard deviation figure as FX rate volatility ( $F X$ vol.), as investors may avoid countries with excessive volatility altogether and this factor could potentially be correlated with our FXD liquidity measures. The latter is constructed using the BIS's monthly real effective exchange rate risk index for all the $j$ host countries.

Finally, following Chan et al. (2005) we also control for the automatic impact of home bias defined as (1- home bias) in all regressions for the source countries (Autohbias). The economic argument is that if investors hold a disproportionately high share of investment in their local market, then the remaining investment in foreign markets should be disproportionately low. We define home bias as:

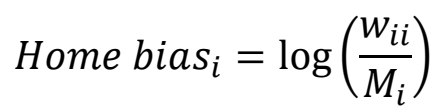

where $w_{i i}$ is the allocation in home country and is computed as:

$$
w_{i i}=\frac{L P H_{i}}{T P H_{i}}
$$

where $L P H_{i}$ is the local portfolio holding by investors in home countries and $T P H_{i}$ is the total portfolio holdings which includes home and foreign investments. The local holding is estimated by deducting the total foreign holdings from the total domestic market capitalization $\left(M C_{i}\right)$ and the total portfolio holdings is computed by adding the home investments to the investments made by all foreigner in the country $i$ as reported by CPIS. $M_{i}$ is the share of local market capitalization in the world market portfolio. Finally, we also include the share of spot FX turnover for each country as the liquidity risks of the spot 
market could also deter investors. All the time varying control measures are either yearly average or year-end values.

\section{Empirical results}

We begin the empirical analysis with the summary statistics on international portfolio allocations, the three measures of market level FXD liquidity risks/trading costs, FX volatility and control variables. We then presents the correlation matrix of all the factors used in our regression analysis for the host countries, followed by the results of alternative regression specifications.

\subsection{Summary statistics}

Table 1 shows summary figures for our five key variables. Panel A reports the figure of individual countries and panel B the average figures of Panel A based on developed and emerging market groups. Column two shows the average foreign equity allocations received by the host countries from investors of all the source countries. In Panel A when we sort the figures of column two from the highest allocations to the lowest it shows nine of the top ten countries are occupied by developed markets. Supporting this in Panel B, the average share of the developed markets in terms of receiving foreign portfolio allocations is $4.5 \%$ compared to approximately $1 \%$ of those received by emerging markets. The figures in Panel A (column two), show that the highest ranked country is the United States followed by the United Kingdom, France, Ireland, Germany, Netherlands, India, Japan, Austria and Switzerland. However, eight of the bottom ten ranked countries are emerging markets (South Africa, Thailand, Mexico, Argentina, Israel, Chile, Philippines and Peru). ${ }^{28}$

\footnotetext{
${ }^{28}$ Although theoretically these allocations should be driven by the size of each country's equity market capitalization in the world market portfolio, existing studies (see Chan et al., 2005) clearly note that foreign investors generally prefer to invest more in developed markets relative to their theoretical prescription. In our multivariate regression analysis we control for all possible factors driving the allocations, including the theoretically prescribed ICAPM benchmark size.
} 
We next focus on the relative rankings in the third column of Table 1 which show the share of each country in the global OTC trading of FXD by location. Similar to figures in column two, we see from Panel B (column three) that the share of the developed markets' currencies is $4.1 \%$ compared to $0.50 \%$ for the emerging markets. As expected Panel A again shows that all the top ten positions are dominated by the currencies of developed countries with the United Kingdom as the leader in the world trading of FXD followed by the United States, Japan, Singapore, Hong Kong, Switzerland, Australia, France, Germany and Denmark. Note the simple correlation coefficient between the average figures of allocations and location based share of trading is 0.62 , which provides an indication that investors seem to prefer markets which have more developed and highly liquid FXD markets.

Although, for the purpose of our study, the location based figures do capture the heterogeneous transaction costs and liquidity risks of FXD markets, investors can extensively trade third party currencies in major financial centres such as the United Kingdom, the United States and Singapore. As such, as an additional measure of FXD trading, we use the relative share of different currencies in the global trading and associate each country with their respective currencies. ${ }^{29}$ Column 4 of Table 1 provides the five year summary of $F X D C B_{j t}$ and panel B shows, similar to the location based measure, that the developed markets' FX trading occupies a significantly higher share in the global trading figures, an average of $8.5 \%$ compared to $0.32 \%$ for the emerging markets. All the top 10 rankings are taken by the developed countries' currencies, with the United States being the major currency of international reserve followed by Japan, the United Kingdom, ${ }^{30}$ Australia, Switzerland, Canada, Sweden, Hong Kong, Norway and New Zealand.

\footnotetext{
${ }^{29}$ However, in the case of the Euro we are not able to distinguish the Euro countries as the relative allocations are not provided by the BIS data.

${ }^{30}$ In terms of currency the Euro occupies the second spot.
} 
On comparing these countries with the allocations, we see that they are ranked among the highest, as noted above. When we shift our attention to the countries whose currencies are thinly traded with relatively underdeveloped FXD markets and hence are lying in the bottom ten, they are all emerging markets (Turkey, Hungary, Chile, Thailand, Malaysia, Israel, Indonesia, Argentina, Peru and Philippines). Correspondingly when we compare these countries with the allocation figures of column 2, they all rank poorly as the recipients of foreign portfolio allocations.

Column five of Table 1 reports (in basis points - bps) the one year bid-ask forward rate to transact a unit US dollar. The average spread of the currencies of developed markets is 16.5 bps compared to 62.2 bps for their emerging markets counterparts. Out of the top ten countries with the lowest spread, seven are developed markets (Singapore, Switzerland, Canada, Japan, United Kingdom, Netherlands and Hong Kong). Whereas, the bottom ten with highest spread are all currencies of emerging markets (Indonesia, Turkey, South Korea, Malaysia, Philippines, Hungary, Brazil, South Africa and Israel). This supports the notion that it is expensive to transact emerging markets' FXD.

Finally, column six (Panel A) reports the three moving average standard deviation figures of the trade weighted real effective FX rate index of individual countries obtained from the BIS. ${ }^{31}$ This figure provides an indication of the real FX risk faced by international investors that is not captured by inflation differentials, i.e. in the scenario where PPP does not hold. Panel B (column six) shows the average volatility of the FX rate for the developed markets' currencies is $4.14 \%$ compared to almost a twice greater figure of $7.15 \%$ for the currencies of emerging markets. The FX volatility figures are particularly important for our study as they clearly show that compared to the developed countries, currencies of most of the emerging markets are highly volatile and hence generate higher FX risks.

\footnotetext{
${ }^{31} \mathrm{We}$ use this measure as a control in the regression analysis.
} 
Following the univariate analysis of Table 1, the figures suggest that investors' allocations are relatively lower in countries/currencies which exhibit higher risks of FX fluctuations (as indicated by the FX volatility figures). Furthermore, the summary analysis of the first three variables (column 2-5) reported in Table 1, provides some reasonable signal that foreign investors' investments seem to be more associated with those markets which provide liquid and cost-effective opportunities to hedge their FX risks

Table 2 reports all the host country-specific control variables used in our regressions. As expected, compared to emerging markets, most of the developed markets rank higher in terms of stock market size (ICAPM benchmark), have a greater trade share with the rest of the world (bilateral trade), are legally more open (capital controls), have more developed stock markets (size and liquidity), rank higher on macroeconomic policy risk and investor protection (higher ranking denotes lower risk) and have higher cross-country correlation.

\section{.Insert Table 2 about here}

\subsection{Correlation and regression results}

In this section we begin our investigation with a pairwise correlation matrix followed by regression estimations.

\subsubsection{Correlation matrix}

Table 3 shows (highlighted in bold) a statistically significant correlation coefficient of $F X D L B$ with country allocation of 0.40 , which is the fourth highest figure for the country allocation figures (column 2). Similarly, the correlation coefficient between $F X D C B$ and country allocation is 0.52 which is the third highest figure among all the bilateral coefficients of country allocations. Note the figure of 0.52 for $F X D C B$ is not 
unexpected as the latter is a FX rate based turnover which better captures the heterogeneity in FXD turnover, i.e. variations in the liquidity risks and transaction costs of FXD markets. However, as we can see, both the FXD turnover factors, i.e. FXDLB and $F X D C B$ have fairly high levels of correlation between them, i.e. 0.62 , indicating they both capture the common variations in the FXD markets' turnover. Finally, correlation figure between country allocations and FXDSB is -0.36 indicating inverse co-movement between country allocations and FXD transaction costs.

The statistically significant correlation coefficients of $0.35,0.38$ and -0.25 between stock market liquidity and the three measures of FXD liquidity (i.e. $F X D L B, F X D C B$, and FXDSB) respectively indicate that highly liquid equity markets also have highly liquid FXD markets. Similarly, the statistically significant correlation coefficients between the three FXD liquidity measures and FX volatility measures are $-0.24,-0.22$ and 0.37 respectively. This further suggests that the liquidity of FXD markets and levels of FX volatility are inversely related, i.e. highly liquid FXD markets also seem to be associated with a lower degree of FX risks. All other correlation coefficient figures are in line with expectations, except for the macroeconomic policy risk and momentum. ${ }^{32}$

\section{Insert Table 3 about here.................}

To summarize, the high and statistically significant coefficient figures of $F X D L B$, $F X D C B$ and $F X D S B$ with country allocations signal that higher (lower) degree of FXD turnover (costs) are associated with higher level of country allocations by foreign investors. We further test the robustness of such association using the different regression specifications.

\footnotetext{
32 Similar results are reported in literature (Gelos and Wei, 2005).
} 


\subsubsection{Regression results}

As noted earlier, one of the advantages of our dataset is the panel set-up which affords us greater statistical advantage in exploiting the wide cross-sectional (40 countries) and temporal (2001-2013) variations. ${ }^{33}$ Given the fact that two of our variables are time invariant (Distance and Language), we use the efficient GLS random effect model in all our regressions but control for the country-specific and time fixed effects. Thus, our econometric method exploits the country and time effects identification strategy. All the $t$ statistics use the cluster-robust standard errors correcting for intra-clustering correlations within individual panels.

We begin our investigation by estimating three regressions for the first measure $\left(F X D L B_{j t}\right)$ of the two turnover based variables, as shown in the specification below (Equation 10):

$$
\log \left(w_{i j t}\right)=\beta \cdot F X D L B_{j t}+\gamma \cdot \text { Controls }+e_{i j t}
$$

The first regression (Equation 10) only includes the ICAPM benchmark and the most widely explained factors of foreign portfolio allocations, i.e. the three bilateral familiarity or information cost factors as controls. The second regression includes the benchmark, bilateral familiarity and the two stock market development factors as control. Finally, the third regression includes all other controls, such as capital control, macroeconomic policy risk, investor protection, diversification potential, automatic impact of home bias, momentum, FX volatility, Spot turnover, country fixed effects (country dummies) and time fixed effects (year dummies). The results of the three regressions are reported in Table 4.

Insert Table 4 about here.

\footnotetext{
${ }^{33}$ Five years in case of BIS turnover based measures.
} 
Table 4 shows that the coefficients of $F X D L B_{j t}$ for all three regressions are statistically significant at a minimum of $5 \%$ significance level. Clearly, the positive sign and the statistical significance provides a strong indication that foreign equity portfolio investors consider the cost and liquidity risks of FXD for hedging their FX risks. In terms of economic significance ${ }^{34}$, the coefficient of 0.520 for $F X D L B$ reported in the third column signifies that, on average, a one percentage increase in the trading value (i.e. $F X D L B)$ of a market might induce foreign investors to increase the allocation by approximately $0.52 \%$.

We next estimate the same three regressions as above, but with $F X D C B_{j t}$ as our key dependent variable as shown in the specification (Equation 11) below:

$$
\log \left(w_{i j t}\right)=\beta \cdot F X D C B_{j t}+\gamma \cdot \text { Controls }+e_{i j t}
$$

Table 5 shows all the coefficients of $F X D C B_{j t}$ are statistically significant (at the $1 \%$ significance level). The FX based turnover factor also provides a robust indication in favour of our view that the liquidity risks and transactions of FXD are important inputs in the cross-country portfolio allocation decision of foreign investors. The reported coefficient of 0.345 related to $F X D C B$ in the third column signifies that one percentage increase in turnover of $\mathrm{FXD}$, on average, may motivate foreign investors to increase allocation in the country by approximately $0.35 \%$.

.Insert Table 5 about here.

Finally, we run similar regression by including the bid-ask spread measure of FXD transaction costs $\left(F X D S B_{j t}\right)$ as shown in Equation 12:

\footnotetext{
${ }^{34}$ As with any other empirical study using econometric modelling, the quantitative interpretation of our coefficients should be exercised with caution.
} 


$$
\log \left(w_{i j t}\right)=\beta . F X D S B_{j t}+\gamma \cdot \text { Controls }+e_{i j t}
$$

The regression results reported in Table 6 show that the spread based measure of transaction costs are all statistically significant at 5\% significance level and bear the expected signs. ${ }^{35}$ The sign implies that higher the spread, i.e. transaction costs; lower is the allocation in the concerned currency/country.

\section{Insert Table 6 about here.}

In terms of the controls and as expected, based on existing literature (see Chan et al., 2005), the most consistent of all are the bilateral familiarity/information cost factors followed by the stock market development, particularly stock market liquidity. Note these factors, along with the FXD liquidity measure and ICAPM benchmark, explain almost $54 \%$ of the total variations in portfolio allocations with only $8 \%$ additional fit being observed by incorporating all other controls, including the country and time dummies. Except the Autohbias, Capital control and Spot turnover, all other factors seem to be sensitive to different specifications as they either become insignificant or change signs. However, such inconsistencies related to all other factors are also reported in the existing literature (see Chan et al, 2005; Gelos and Wei, 2005). In the following sections, we conduct additional tests to ensure our results are robust to different theoretical and econometric specifications.

\subsubsection{Dealing with endogeneity}

In all our above specifications we dealt with the issue of omitted variable bias, including country and time effects. Errunza (2001) notes that the growing investment

\footnotetext{
35 The results in second column use data for 13-year period (2001-2013). However, the inclusion of Spot turnover, which is only available for five year period (2001, 2004, 2007, 2010, and 2013) from BIS drops the number of observations in the third column.
} 
activities of foreign investors may demand reforms in the capital market, implying that greater foreign investments can encourage the development of the FXD markets, leading to greater availability of hedging possibilities. If this conjecture holds, then all our FXD liquidity factors can suffer from endogeneity problems arising from reverse causality. Following Gelos and Wei (2005) in Equation 13 below, we estimate the full specification but using a predetermined, one period, lagged value of the three measures of FXD liquidity, $\left(F X D_{j, t-1}\right)$ i.e. $F X D L B_{j t-1}, F X D C B_{j t-1}$ and $F X D S B_{j t-1}$ :

$$
\log \left(w_{i j t}\right)=\beta \cdot F X D_{j, t-1}+\gamma \cdot \text { Controls }+e_{i j t}
$$

Table 7 shows that all the three lagged factors are statistically significant. Note that the sizes of the estimates do not substantially alter, even though the variables represent a lagged rather than a level effect, along with the loss of one year's observations. These results provide strong support to our assertion that even after addressing the reverse causality issue, FXD liquidity seems to significantly influence the cross-country portfolio allocation decision of foreign investors.

\section{Insert Table 7 about here}

\subsubsection{Tradability in major financial centres}

Table 1 shows that countries having major financial centres, principally the United Kingdom and the United States, are the major recipients of foreign investment. These are generally considered to be major financial centres where FXD are traded and hence, our results could be driven by these major currencies. Further, the trades on these currencies can also cover third country exposures, predominantly of smaller emerging markets, through cross hedging. This could again question our results. We address this issue by reestimating the complete specifications of Equations 10, 11, and 12 but by excluding some 
of the major financial trading centres, such as the United States, the United Kingdom, Japan, Singapore, Hong Kong and Netherlands from our sample as source and host countries.

Table 8 shows the coefficients of all the three FXD liquidity measures are still statistically significant, although the size of the estimates now changes, which is not unexpected as the estimation now uses different levels of information in the dataset. However, we see that our key findings remain intact even when we take the major financial centre countries out of the sample.

..Insert Table 8 about here

\subsubsection{Float adjusted benchmark}

Dahlquist et al. (2003) show that not all stocks in different countries are freely available to foreign investors. This implies that, despite the theoretical ground, investors may not hold the world market portfolio. If stocks are not freely floated, our results may be biased with the usage of the total world market portfolio as the benchmark. We address this by re-constructing the benchmark, using equation no. 3 (see section 2.1), based on the proportion of freely available market capitalization of Dahlquist et al. (2003) and re-run the complete specifications of Equations 10,11 and 12. The results are reported in Table $8 .^{36}$

\footnotetext{
${ }^{36}$ As an alternative measure, we also use the S\&P/IFCI market capitalization, which is the investable market capitalization, to construct the benchmark. The results of the regression are qualitatively similar. However, since this measure is only available for emerging markets, we do not report these results in our paper.
} 
The statistically significant coefficients of all the three relevant factors further support our view that even after controlling for the possibility of free float issue, foreign investors prefer to invest in those countries which have highly liquid FXD markets to hedge the FX risks of their international portfolio investments.

\subsubsection{Alternative measure}

It can be argued that the two FXD turnover measures are based on their relative share in the global trading activities of FXD, but they might not capture trading activities relative to the size of their financial markets in which the trading takes place. In order to address the effect of relative size of the corresponding economies, we employ an additional scaling method to the total turnover figures reported in the BIS's 2013 TCBS statistics (Table 19), which include the yearly figure of the average daily spot and FXD trading (in billion USD) in the month of April. We scale the aggregate figure by each country's equity market capitalization (in billion USD) and use it as an additional proxy reflecting the heterogeneous degree of liquidity risks and transaction costs of FXD markets relative to the size of the financial market. We denote this factor as $F X D_{-} t o_{-} M C A P_{j t}$ and estimate the following regression in equation 14 :

$$
\log \left(w_{i j t}\right)=\beta . F X D_{-} t o_{-} M C A P_{j t}+\gamma . \text { Controls }+e_{i j t}
$$

Table 9 shows the highly statistically significant estimate of $F X D_{-} t o_{-} M C A P_{j t}$ (0.513), (at a 1\% significance level), and this indicates that economies which have highly liquid FXD markets relative to the size of their economy attract higher levels of foreign portfolio investments. 


\section{Conclusion}

The literature suggests that despite the benefits of international diversification opportunities, portfolio investments are exposed to FX risks. In terms of modelling expected returns and optimizing the global portfolio, prior studies note that investors who hedge their FX risks using FXD improve their risk-return profile. However, foreign investors' hedging prospects are constrained by the varying degrees of liquidity risks and transaction costs of FXD markets. In this study we investigate whether portfolio investors' cross-country portfolio allocation decisions are influenced by the liquidity risks and transaction costs of FXD. Using an extensive dataset with wide cross-sectional (developed and emerging markets) and temporal (four years) variations, and employing robust analytical techniques, we report the following key findings.

Our univariate analysis reports significant variations in liquidity levels of FXD markets. Our results report that compared to their developed counterparts, developing countries have smaller and relatively illiquid FXD markets. Such relatively undeveloped FXD markets generate higher liquidity risks and transaction costs for effectively hedging the FX risks of international portfolios. Similarly, our extensive and robust regression correlation and regression results provide convincing evidence that foreign investors tend to allocate more wealth to countries which have bigger and more liquid FXD markets offering liquid and cost-effective prospects of hedging the FX risks of their international portfolio investments. The overall results, which are robust to various alternative specifications, imply that reforms aimed at developing the FXD markets could be a potential policy measure for attracting higher levels of foreign equity portfolio investments. 


\section{References}

Baltagi, B.H. (2008). Econometric Analysis of Panel Data, New York: John Wiley and Sons.

Banti, C., \& Phylaktis, K. (2015). FX market liquidity, funding constraints and capital flows. Journal of International Money and Finance, 56, 114-134.

Bartram, S.M., Brown, G.W., \& Fehle, F.R. (2009). International evidence on financial derivative usage. Financial Management, 38, 185-206.

Bekaert, G., Harvey, C.R., \& Lundblad, C. (2007). Liquidity and expected returns: lessons from emerging markets. The Review of Financial Studies, 20, 1783-1831.

Bekaert, G., \& Hodrick, R. (2012). International Financial Management (2 ${ }^{\text {nd }}$ Ed), New Jersey: Pearson Education.

Bodnar, G.M., Hayt, G.S., \& Marston, R.C. (1996). Wharton survey of derivatives usage by US non-financial firms. Financial Management, 25, 113-133.

Bohn, H., \& Tesar, L.L. (1996). U.S. equity investment in foreign markets: Portfolio rebalancing or return chasing? American Economic Review, 86, 77-81.

Campello, M., Lin C., Ma, Y., \& Zou, H. (2011). The real and financial implications of corporate hedging. Journal of Finance, 66, 1615 - 1647.

Cao, C., Ghysels, E., \& Hatheway, F. (2011). Derivatives do affect mutual fund returns: Evidence from the financial crisis of 1998. The Journal of Futures Market, 31, 629-658.

Carrieri, F., Errunza, V., \& Majerbi, B. (2006). Does emerging market exchange rate affect equity price? Journal of Financial and Quantitative Analysis, 41, 511-540.

Chan, K., Covrig, V., \& Ng, L. (2005). What determines the domestic bias and foreign bias? Evidence from mutual fund equity allocations worldwide. Journal of Finance, 60, $1495-1534$

Chong, L.L., Chang, X-J, \& Tan, S-H (2014). Determinants of corporate foreign exchange risk hedging, Managerial Finance, 40, 176-188.

Cooper, I., \& Kaplanis, E. (1986). Costs to cross border investment and international equity market equilibrium. In: Edwards, J., Franks, J., Mayer, C., Schaefer, S. (Eds.), Recent Developments in Corporate Finance (pp. 209-240), New York: Cambridge University Press.

Culp, C. L \& Mackay, R. J. (1994). Regulating derivatives: The current system and proposed changes. Regulation, 4, 38-51.

Dahlquist, M., Pinkowitz, L., Stulz, R.M., \& Williamson, R. (2003). Corporate governance and the home bias. Journal of Financial and Quantitative Analysis, 38, 87-110. 
De Jong, F., \& de Roon, F.A. (2005). Time-varying market integration and expected returns in emerging markets. Journal of Financial Economics, 78, 583-613.

De Santis, G., \& Gerard, B. (1998). How big is the premium for currency risk? Journal of Financial Economics, 49, 375-412.

Duffie, D, Li, A., \& Lubke, T. (2010). Policy perspective on OTC derivatives market infrastructure. Federal Reserve Bank of New York Staff Reports, 424, 1-25.

Dumas, D., \& Solnik, M. (1995). The world price of foreign exchange risk. Journal of Finance, 50, 445-479.

Errunza, V. (2001). Foreign portfolio equity investments, financial liberalization, and economic development. Review of International Economics, 9, 703-726.

Eun, C., \& Resnick, B. (1988). Exchange rate uncertainty, forward contracts and international portfolio selection. Journal of Finance, 43, 197-215.

Eun, C., \& Resnick, B. (1994). International diversification of investment portfolios: US and Japanese perspectives. Management Science, 40, 140-161.

Fidora, M., Fratzscher, M., \& Thimann, C. (2007). Home bias in global bond and equity markets: The role of real exchange rate volatility. Journal of International Money and Finance, 26, 631-655.

Gelos, R.G., \& Wei, S-J. (2005). Transparency and international portfolio holdings. Journal of Finance, 60, 2987-3020.

Glen, J., \& Jorion, P. (1993). Currency hedging for international portfolios. Journal of Finance, 48, 1865-1886.

Goyenko, R. Y., Holden, C. W., \& Trzcinka, C. A. (2009). Do liquidity measures measure liquidity? Journal of Financial Economics, 92(2), 153-181

Henderson, C. (2002). Editorial: Hedging emerging market currency risk. Derivative Use, Trading and Regulation, 8, 5-12.

Jorion, P. (1989). Asset allocation with hedged and unhedged foreign stocks and bonds. Journal of Portfolio Management, 15, 49-54.

Jorion, P. (1993). Currency hedging of international portfolios. Journal of Finance, 68, $1865-1866$.

La Porta, R., Lopez-De-Silanes, F., Shleifer, A., \& Vishny, R.W. (1998). Law and finance. Journal of Political Economy, 106, 1113-1155.

Levine, R. \& Zervos, S. (1998a), Stock markets, banks, and economic growth. American Economic Review, 88, 537-558.

Levine, R., \& Zervos, S. (1998b). Capital control liberalization and stock market development. World Development, 26, 1169-1183. 
Madura, J., \& Fox, R. (2011). International Financial Management. (2 ${ }^{\text {nd }}$ Ed). United Kingdom: Cengage Learning EMEA.

Mihaljek, D., \& Packer, F. (2010). Derivatives in emerging markets. BIS Quarterly Review, December, 43-58.

Perold, A.F., \& Schulman, E.C. (1988). The free lunch in currency hedging: Implications for investment policy and performance standards. Financial Analyst Journal, 44, 45-50.

Portes, R., \& Rey, H. (2005). The determinants of cross-border equity flows. Journal of International Economics, 65, 269-296.

Richards, A. (2005). Big fish in small ponds: The trading behaviour and price impact of foreign investors in Asian equity markets. Journal of Financial and Quantitative Analysis, 40, 1-27.

Subramanian, A., \& Wei, S-J. (2007). The WTO promotes trade, strongly but unevenly. Journal of International Economics, 72, 151-175.

Triennial Central Bank Survey (2013), Foreign exchange turnover in April 2013: preliminary global results, Bank of International Settlement, September 2013.

Zhou, V. Y., \& Wang, P. (2013). Managing foreign exchange risk with derivatives in UK non-financial firms, International Review of Financial Analysis 29, 294-302 
Appendix - Source and host countries

\begin{tabular}{|c|c|}
\hline Source countries & Host countries \\
\hline Developed markets & Developed markets \\
\hline Australia & Australia \\
\hline Austria & Austria \\
\hline Belgium & Belgium \\
\hline Canada & Canada \\
\hline Denmark & Denmark \\
\hline Finland & Finland \\
\hline France & France \\
\hline Germany & Germany \\
\hline Greece & Greece \\
\hline Hong Kong & Hong Kong \\
\hline Iceland & Ireland \\
\hline Ireland & Italy \\
\hline Israel & Japan \\
\hline Italy & Netherlands \\
\hline Japan & New Zealand \\
\hline Netherlands & Norway \\
\hline New Zealand & Portugal \\
\hline Norway & Spain \\
\hline Portugal & Sweden \\
\hline Spain & Switzerland \\
\hline Sweden & United Kingdom \\
\hline Switzerland & United States \\
\hline \multicolumn{2}{|l|}{ United Kingdom } \\
\hline \multirow[t]{2}{*}{ United States } & Emerging markets \\
\hline & Argentina \\
\hline Emerging markets & Brazil \\
\hline Argentina & Chile \\
\hline Bahrain & China \\
\hline Brazil & Hungary \\
\hline Bulgaria & India \\
\hline Chile & Indonesia \\
\hline Colombia & Israel \\
\hline Costa Rica & Malaysia \\
\hline Cyprus & Mexico \\
\hline Czech Republic & Peru \\
\hline Estonia & Philippines \\
\hline Egypt & Poland \\
\hline Hungary & Singapore \\
\hline India & South Africa \\
\hline Indonesia & South Korea \\
\hline Kazakhstan & Thailand \\
\hline Latvia & Turkey \\
\hline \multicolumn{2}{|l|}{ Lithuania } \\
\hline \multicolumn{2}{|l|}{ South Korea } \\
\hline \multicolumn{2}{|l|}{ Kuwait } \\
\hline \multicolumn{2}{|l|}{ Lebanon } \\
\hline \multicolumn{2}{|l|}{ Malaysia } \\
\hline \multicolumn{2}{|l|}{ Mauritius } \\
\hline \multicolumn{2}{|l|}{ Mexico } \\
\hline \multicolumn{2}{|l|}{ Pakistan } \\
\hline \multicolumn{2}{|l|}{ Panama } \\
\hline \multicolumn{2}{|l|}{ Philippines } \\
\hline \multicolumn{2}{|l|}{ Poland } \\
\hline \multicolumn{2}{|l|}{ Romania } \\
\hline \multicolumn{2}{|l|}{ Russia } \\
\hline \multicolumn{2}{|l|}{ Singapore } \\
\hline Slovenia & \\
\hline South Africa & \\
\hline Thailand & \\
\hline Turkey & \\
\hline Ukraine & \\
\hline Uruguay & \\
\hline Venezuela & \\
\hline
\end{tabular}


Table 1: Summary Figures

The first column represents the host countries used in this study and all the figures in columns 2 and 3 are based on a five year average (2001, 2004, 2007, 2010 and 2013). Figures in columns 1, 3 and 4 are averaged over a period of 20012013. The second column figures, i.e., Country allocations, are the cross-country equity portfolio allocations ( $\left.w_{i j t}\right)$ of investors domiciled in source country $i$ into host country $j(i \neq j)$.). The third and fourth columns respectively present the share of each $j$ country in the global location and currency based FXD trading activities, i.e. daily average turnover of FXD, which includes forward contracts, FX swaps, currency swaps and options. FXDLB present the share of location based daily average turnover of FXD in the world turnover for each host country. FXDCB is the share of currency based FXD of daily average turnover of FXD in the world turnover for each host country. FXDSB is the yearly average bid-ask spread of the respective countries' currencies against the US dollar in basis points. $F X$ volatility reflects real exchange rate risk and is measured as a three year moving average standard deviation using the real effective exchange rate index of the Bank of International Settlement.

Panel A: Individual Countries

\begin{tabular}{|c|c|c|c|c|c|}
\hline \multirow[b]{2}{*}{ Country } & \multirow[b]{2}{*}{$\begin{array}{c}\text { Country } \\
\text { allocations }(\%)\end{array}$} & \multicolumn{3}{|c|}{ FXD Liquidity Measures } & \multirow[b]{2}{*}{$\begin{array}{c}\text { FX vol. } \\
(\%)\end{array}$} \\
\hline & & $\begin{array}{c}\text { FXDLB } \\
(\%)\end{array}$ & $\begin{array}{c}\text { FXDCB } \\
(\%)\end{array}$ & $\begin{array}{c}\text { FXDSB } \\
\text { (bps) }\end{array}$ & \\
\hline Argentina & 0.287 & 0.001 & 0.024 & NA & 10.019 \\
\hline Australia & 2.482 & 3.885 & 4.256 & 23.492 & 8.071 \\
\hline Austria & 3.132 & 0.418 & NA & NA & 1.938 \\
\hline Belgium & 1.416 & 0.783 & NA & NA & 2.313 \\
\hline Brazil & 1.122 & 0.133 & 0.38 & 44.844 & 12.212 \\
\hline Canada & 1.223 & 1.851 & 2.906 & 12.295 & 5.753 \\
\hline Chile & 0.12 & 0.084 & 0.111 & NA & 7.477 \\
\hline China & 2.262 & 0.197 & 0.502 & 9.875 & 4.754 \\
\hline Denmark & 0.474 & 2.095 & 0.537 & 22.612 & 2.395 \\
\hline Finland & 1.532 & 0.351 & NA & NA & 2.84 \\
\hline France & 7.018 & 3.515 & NA & NA & 2.482 \\
\hline Germany & 5.8 & 3.46 & NA & NA & 3.156 \\
\hline Greece & 0.627 & 0.137 & NA & NA & 4.398 \\
\hline Hong Kong & 1.902 & 4.931 & 1.338 & 4.079 & 4.499 \\
\hline Hungary & 0.686 & 0.098 & 0.181 & 53.647 & 7.322 \\
\hline India & 3.239 & 0.414 & 0.431 & 10.604 & 5.381 \\
\hline Indonesia & 0.632 & 0.049 & 0.081 & 180.935 & 9.792 \\
\hline Ireland & 5.917 & 0.263 & NA & NA & 3.725 \\
\hline Israel & 0.14 & 0.135 & 0.087 & 41.404 & 5.288 \\
\hline Italy & 2.095 & 0.75 & NA & NA & 2.505 \\
\hline Japan & 3.165 & 7.018 & 13.091 & 11.675 & 7.876 \\
\hline Malaysia & 0.621 & 0.091 & 0.127 & 85.347 & 3.525 \\
\hline Mexico & 0.385 & 0.398 & 0.904 & 16.605 & 7.794 \\
\hline Netherlands & 4.101 & 1.387 & NA & 4.633 & 3.076 \\
\hline New Zealand & 0.083 & 0.276 & 0.925 & 41.177 & 7.606 \\
\hline Norway & 0.549 & 0.697 & 0.975 & 20.841 & 5.087 \\
\hline Peru & 0.092 & 0.008 & 0.015 & NA & 4.064 \\
\hline Philippines & 0.097 & 0.053 & 0.076 & 84.453 & 5.173 \\
\hline Poland & 0.926 & 0.208 & 0.405 & 27.835 & 8.191 \\
\hline Portugal & 0.499 & 0.069 & NA & NA & 1.972 \\
\hline Singapore & 1.918 & 5.685 & 0.762 & 17.505 & 2.918 \\
\hline South Africa & 0.433 & 0.429 & 0.562 & 43.726 & 11.803 \\
\hline South Korea & 0.886 & 0.609 & 0.746 & 116.156 & 6.834 \\
\hline Spain & 2.185 & 0.562 & NA & NA & 2.664 \\
\hline Sweden & 2.16 & 1.211 & 1.437 & 22.998 & 4.806 \\
\hline Switzerland & 2.987 & 4.553 & 3.853 & 13.215 & 4.684 \\
\hline Thailand & 0.401 & 0.145 & 0.136 & 28.028 & 3.816 \\
\hline Turkey & 0.705 & 0.251 & 0.321 & 172.934 & 12.356 \\
\hline United Kingdom & 12.919 & 36.848 & 8.788 & 4.905 & 5.049 \\
\hline United States & 36.744 & 14.808 & 55.196 & NA & 4.241 \\
\hline \multicolumn{6}{|c|}{ Panel B: Developed versus Emerging Countries } \\
\hline Developed markets & 4.500 & 4.085 & 8.482 & 16.538 & 4.143 \\
\hline Emerging markets & 0.831 & 0.499 & 0.325 & 62.260 & 7.151 \\
\hline
\end{tabular}

Note: All the mean difference figures are statistically significant at $1 \%$ significance level. 
Table 2: Summary of control variables

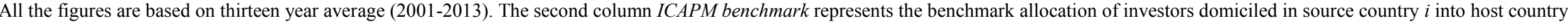

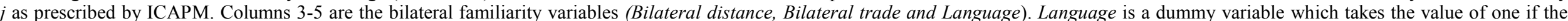

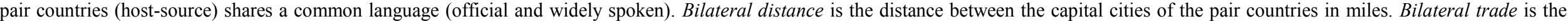

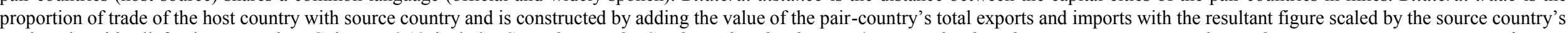

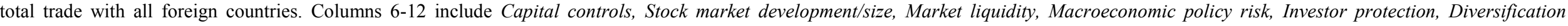
potential and Momentum measures respectively. For each host country, Capital control represent capital market openness, which ranges from 0 to 10 , with 0 reflecting completely closed markets and

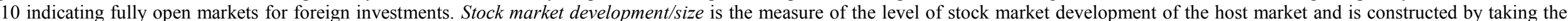

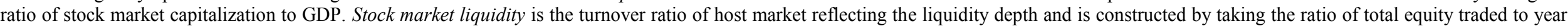

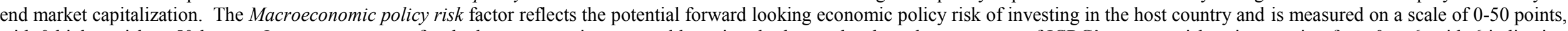

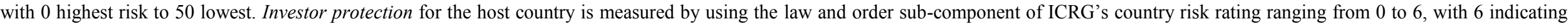
potentially the lowest risk in terms of formulating the quality of legal rules and their observance. Diversification potential is correlation of stock returns between the pair-countries and is constructed

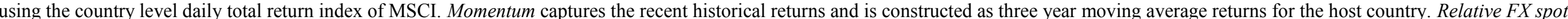
is the share of each countries share in global FX spot transaction.

\section{Panel A: Individual Countries}

\begin{tabular}{|c|c|c|c|c|c|c|c|c|c|c|c|c|c|}
\hline Country & $\begin{array}{c}\text { ICAPM } \\
\text { benchmark } \\
(\%)\end{array}$ & $\begin{array}{c}\text { Bilateral } \\
\text { distance } \\
\text { (miles) }\end{array}$ & $\begin{array}{c}\text { Bilateral } \\
\text { trade } \\
(0-1)\end{array}$ & $\begin{array}{c}\text { Common } \\
\text { language } \\
(0-1)\end{array}$ & $\begin{array}{l}\text { Stock market } \\
\text { dev./size (\% of } \\
\text { GDP) }\end{array}$ & $\begin{array}{c}\text { Stock } \\
\text { market } \\
\text { liquidity } \\
(\% \text { of } M C)\end{array}$ & $\begin{array}{l}\text { Capital } \\
\text { control } \\
(0-10)\end{array}$ & $\begin{array}{c}\text { Macroeconomic } \\
\text { policy risk } \\
(0-50)\end{array}$ & $\begin{array}{l}\text { Investor } \\
\text { protection } \\
(0-6)\end{array}$ & $\begin{array}{l}\text { Corr. } \\
(0-1)\end{array}$ & $\begin{array}{l}\text { Momentum } \\
\text { (\%) }\end{array}$ & $\begin{array}{l}\text { FX } \\
\text { vol. } \\
\text { (\%) }\end{array}$ & $\begin{array}{c}\text { Relative FX } \\
\text { spot (\%) }\end{array}$ \\
\hline Argentina & 0.050 & 6464 & 0.142 & 0.006 & 26.43 & 8.36 & 5.68 & 37.29 & 2.64 & 0.37 & 16.56 & 10.02 & 0.094 \\
\hline Australia & 2.409 & 7145 & 0.313 & 0.007 & 111.05 & 85.51 & 7.56 & 39.57 & 5.67 & 0.31 & 6.51 & 8.07 & 3.395 \\
\hline Austria & 0.186 & 1931 & 0.036 & 0.005 & 27.28 & 46.78 & 7.48 & 39.91 & 6.00 & 0.49 & 3.49 & 1.94 & 0.492 \\
\hline Belgium & 0.600 & 2075 & 0.117 & 0.012 & 62.14 & 44.42 & 7.78 & 40.63 & 5.00 & 0.53 & -2.00 & 2.31 & 0.624 \\
\hline Brazil & 1.715 & 5672 & 0.018 & 0.011 & 54.21 & 55.01 & 6.15 & 36.34 & 2.03 & 0.41 & 21.36 & 12.21 & 0.512 \\
\hline Canada & 3.320 & 4639 & 0.354 & 0.006 & 111.73 & 73.57 & 7.37 & 41.09 & 5.80 & 0.40 & 6.07 & 5.75 & 1.459 \\
\hline Chile & 0.326 & 6531 & 0.142 & 0.003 & 110.81 & 16.22 & 7.99 & 40.18 & 4.83 & 0.39 & 15.37 & 7.48 & 0.273 \\
\hline China & 2.517 & 4603 & 0.021 & 0.042 & 64.69 & 139.11 & 5.87 & 39.98 & 4.21 & 0.37 & 17.31 & 4.75 & 0.743 \\
\hline Denmark & 0.412 & 2072 & 0.306 & 0.005 & 62.35 & 76.24 & 7.50 & 41.14 & 6.00 & 0.49 & 6.29 & 2.39 & 1.479 \\
\hline Finland & 0.529 & 2502 & 0.018 & 0.005 & 84.72 & 114.59 & 7.94 & 42.42 & 6.00 & 0.50 & 1.45 & 2.84 & 0.101 \\
\hline France & 4.665 & 2187 & 0.071 & 0.022 & 74.61 & 94.44 & 7.23 & 37.77 & 4.94 & 0.57 & 0.50 & 2.48 & 1.871 \\
\hline Germany & 3.276 & 1946 & 0.054 & 0.048 & 42.81 & 132.75 & 7.57 & 40.72 & 5.00 & 0.54 & 1.70 & 3.16 & 2.888 \\
\hline Greece & 0.211 & 2288 & 0.000 & 0.004 & 40.01 & 47.92 & 6.06 & 33.16 & 4.12 & 0.44 & -7.04 & 4.40 & 0.126 \\
\hline Hong Kong & 1.342 & 4817 & 0.326 & 0.006 & 420.58 & 94.55 & 8.93 & 44.51 & 4.87 & 0.38 & 9.78 & 4.50 & 3.379 \\
\hline Hungary & 0.068 & 2438 & 0.000 & 0.003 & 22.08 & 75.87 & 7.52 & 34.15 & 4.00 & 0.40 & 8.77 & 7.32 & 0.082 \\
\hline India & 1.532 & 4171 & 0.301 & 0.009 & 69.68 & 97.36 & 6.32 & 34.04 & 4.00 & 0.33 & 18.16 & 5.38 & 0.750 \\
\hline Indonesia & 0.360 & 5934 & 0.000 & 0.005 & 34.06 & 47.24 & 6.65 & 36.60 & 2.79 & 0.31 & 21.78 & 9.79 & 0.218 \\
\hline Ireland & 0.205 & 2483 & 0.308 & 0.003 & 47.22 & 39.70 & 8.68 & 37.14 & 6.00 & 0.45 & -8.37 & 3.72 & 0.398 \\
\hline Israel & 0.264 & 2796 & 0.294 & 0.002 & 75.43 & 58.28 & 7.35 & 39.62 & 5.00 & 0.33 & 7.98 & 5.29 & 0.259 \\
\hline Italy & 1.729 & 2116 & 0.018 & 0.021 & 32.31 & 146.06 & 5.30 & 37.09 & 4.06 & 0.55 & -3.07 & 2.50 & 0.766 \\
\hline Japan & 9.202 & 5274 & 0.000 & 0.024 & 73.96 & 110.46 & 6.34 & 38.67 & 5.00 & 0.29 & -4.65 & 7.88 & 7.639 \\
\hline Malaysia & 0.612 & 5404 & 0.000 & 0.008 & 140.98 & 31.32 & 6.99 & 40.36 & 3.80 & 0.30 & 10.08 & 3.53 & 0.186 \\
\hline Mexico & 0.653 & 5806 & 0.142 & 0.006 & 31.66 & 27.32 & 7.25 & 36.44 & 2.36 & 0.44 & 16.19 & 7.79 & 0.619 \\
\hline
\end{tabular}




\begin{tabular}{|c|c|c|c|c|c|c|c|c|c|c|c|c|c|}
\hline Netherlands & 1.289 & 2000 & 0.018 & 0.018 & 82.75 & 129.85 & 7.77 & 41.09 & 6.00 & 0.55 & 0.57 & 3.08 & 1.318 \\
\hline New Zealand & 0.057 & 8616 & 0.306 & 0.001 & 40.60 & 40.95 & 7.77 & 37.38 & 5.65 & 0.19 & 2.89 & 7.61 & 0.141 \\
\hline Norway & 0.490 & 2274 & 0.000 & 0.005 & 53.41 & 103.44 & 7.04 & 46.60 & 6.00 & 0.51 & 7.15 & 5.09 & 0.291 \\
\hline Peru & 0.095 & 5836 & 0.159 & 0.002 & 50.75 & 6.53 & 7.31 & 37.91 & 3.16 & 0.35 & 25.21 & 4.06 & 0.060 \\
\hline Philippines & 0.148 & 5436 & 0.302 & 0.002 & 60.68 & 18.79 & 6.00 & 37.18 & 2.35 & 0.18 & 9.19 & 5.17 & 0.070 \\
\hline Poland & 0.248 & 2445 & 0.000 & 0.006 & 30.35 & 41.24 & 6.15 & 36.20 & 4.36 & 0.43 & 5.37 & 8.19 & 0.194 \\
\hline Portugal & 0.187 & 2798 & 0.018 & 0.002 & 35.80 & 58.37 & 6.82 & 33.93 & 5.00 & 0.46 & -1.94 & 1.97 & 0.115 \\
\hline Singapore & 0.657 & 5295 & 0.301 & 0.010 & 165.82 & 66.75 & 8.79 & 44.81 & 5.14 & 0.43 & 7.24 & 2.92 & 6.165 \\
\hline South Africa & 0.885 & 5721 & 0.319 & 0.003 & 184.84 & 51.75 & 6.77 & 35.19 & 2.36 & 0.43 & 14.69 & 11.80 & 0.285 \\
\hline South Korea & 1.758 & 4988 & 0.306 & 0.011 & 76.19 & 206.62 & 6.15 & 41.45 & 4.84 & 0.34 & 14.03 & 6.83 & 1.215 \\
\hline Spain & 1.562 & 2633 & 0.144 & 0.012 & 81.46 & 150.52 & 7.00 & 36.55 & 4.83 & 0.55 & 2.92 & 2.66 & 0.593 \\
\hline Sweden & 1.062 & 2234 & 0.018 & 0.009 & 98.61 & 111.71 & 8.02 & 42.80 & 6.00 & 0.53 & 4.99 & 4.81 & 0.775 \\
\hline Switzerland & 2.795 & 2014 & 0.126 & 0.008 & 200.89 & 93.29 & 7.71 & 44.05 & 5.06 & 0.53 & 0.50 & 4.68 & 4.644 \\
\hline Thailand & 0.404 & 4828 & 0.302 & 0.006 & 70.92 & 88.67 & 6.32 & 37.87 & 2.85 & 0.32 & 12.71 & 3.82 & 0.181 \\
\hline Turkey & 0.373 & 2462 & 0.000 & 0.005 & 31.33 & 149.28 & 6.44 & 32.51 & 4.10 & 0.39 & 26.72 & 12.36 & 0.195 \\
\hline United Kingdom & 8.031 & 2255 & 0.306 & 0.023 & 120.12 & 131.18 & 8.38 & 36.83 & 5.58 & 0.53 & 2.92 & 5.05 & 30.222 \\
\hline United States & 40.737 & 5254 & 0.302 & 0.068 & 117.28 & 197.50 & 7.24 & 37.33 & 5.09 & 0.36 & 1.17 & 4.24 & 28.155 \\
\hline \multicolumn{14}{|c|}{ Panel B: Developed versus Emerging Countries } \\
\hline Developed markets & 3.832 & 3252 & 0.144 & 0.014 & 91.90 & 96.54 & 7.43 & 39.56 & 5.35 & 0.46 & 1.45 & 4.14 & 4.131 \\
\hline Emerging markets & 0.704 & 4824 & 0.153 & 0.008 & 72.27 & 65.87 & 6.76 & 37.67 & 3.60 & 0.36 & 14.93 & 7.15 & 0.672 \\
\hline
\end{tabular}




\section{Table 3: Correlation matrix}

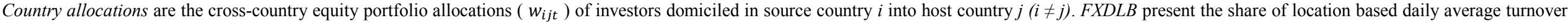

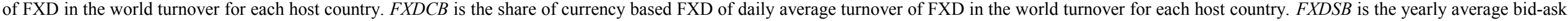

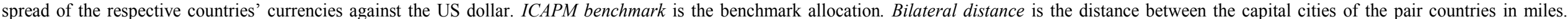

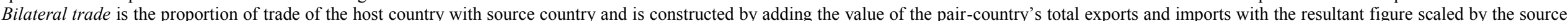

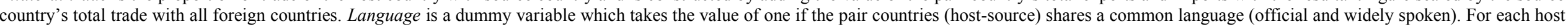

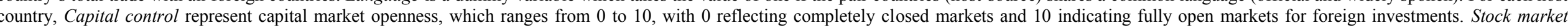

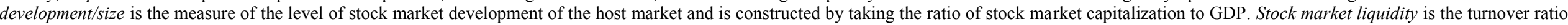

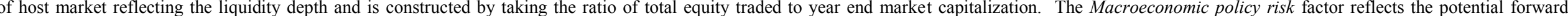

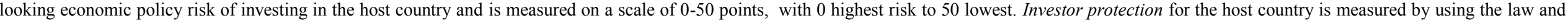

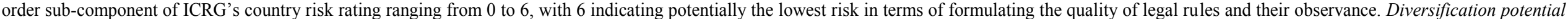

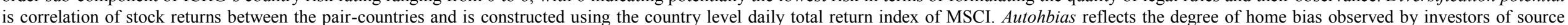

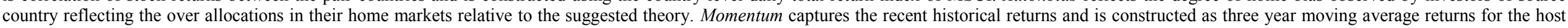

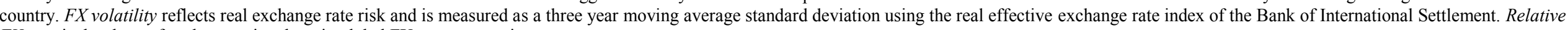
FX spot is the share of each countries share in global FX spot transaction

\begin{tabular}{|c|c|c|c|c|c|c|c|c|c|c|c|c|c|c|c|c|c|}
\hline & (1) & (2) & (3) & (4) & (5) & (6) & (7) & (8) & (9) & (10) & (11) & (12) & (13) & (14) & (15) & (16) & (17) \\
\hline Country allocations (1) & 1 & & & & & & & & & & & & & & & & \\
\hline FXDLB (2) & $0.40^{* * *}$ & 1 & & & & & & & & & & & & & & & \\
\hline FXDCD (3) & $0.52 * * *$ & $0.62 * * *$ & 1 & & & & & & & & & & & & & & \\
\hline FXDSB (4) & $-0.36 * * *$ & $-0.14 * * *$ & $-0.18^{* * *}$ & 1 & & & & & & & & & & & & & \\
\hline ICAPM benchmark (5) & $0.64^{* *}$ & $0.5^{* * * *}$ & $0.67^{* * * *}$ & $-0.27^{* * *}$ & 1 & & & & & & & & & & & & \\
\hline Bilateral distance (6) & $-0.3^{* * *}$ & $-0.11^{* * *}$ & 0.01 & 0.00 & $0.04^{*}$ & 1 & & & & & & & & & & & \\
\hline Bilateral trade (7) & $0.54^{* * *}$ & $0.31^{* * *}$ & $0.36^{* * *}$ & $-0.1^{* * *}$ & $0.49 * * *$ & $-0.42^{* * *}$ & 1 & & & & & & & & & & \\
\hline Language (8) & $0.19^{* * *}$ & $0.09 * * *$ & -0.03 & $-0.06^{* * *}$ & 0.01 & $0.04 *$ & $0.14^{* * *}$ & 1 & & & & & & & & & \\
\hline Capital control (9) & $0.16^{* * *}$ & $0.33^{* * *}$ & $0.14 * * *$ & 0.02 & 0.03 & $-0.07 * * *$ & 0.01 & $0.09^{* * *}$ & 1 & & & & & & & & \\
\hline Stock market dev./size (10) & $0.32^{* * *}$ & $0.26^{* * *}$ & $0.17^{* * *}$ & $-0.25^{* * *}$ & $0.55^{* * *}$ & $0.06^{* * *}$ & $0.15^{* * *}$ & $0.17^{* * *}$ & $0.35^{* * *}$ & 1 & & & & & & & \\
\hline Stock market liquidity (11) & $0.27^{* * *}$ & $0.35^{* * *}$ & $0.38^{* * *}$ & $-0.25^{* *}$ & $0.48^{* * *}$ & $-0.11^{* * *}$ & $0.33^{* * *}$ & -0.02 & -0.01 & $0.16^{* * *}$ & 1 & & & & & & \\
\hline Macroeconomic policy risk (12) & $0.16^{* * *}$ & -0.03 & 0.02 & $-0.33^{* * *}$ & $0.20 * * *$ & $-0.07^{* * *}$ & $0.07^{* * *}$ & $0.04 *$ & $0.39^{* * *}$ & $0.51^{* * *}$ & $0.17^{* * *}$ & 1 & & & & & \\
\hline Investor protection (13) & $0.22 * * *$ & $0.3^{* * * *}$ & $0.34 * * *$ & $-0.19^{* * *}$ & $0.27 * * *$ & $-0.19^{* * *}$ & $0.11^{* * *}$ & $0.06^{* * *}$ & $0.43^{* * *}$ & $0.27^{* * *}$ & $0.42 * * *$ & $0.49^{* * *}$ & 1 & & & & \\
\hline Diversification potential (14) & $0.32 * * *$ & $0.17 * * *$ & 0.03 & $-0.21 * * *$ & $0.25 * * *$ & $-0.57^{* * *}$ & $0.31^{* * *}$ & $-0.04 *$ & -0.02 & $0.20^{* * *}$ & $0.21^{* * *}$ & $0.15^{* * *}$ & $0.15^{* * *}$ & 1 & & & \\
\hline Autohbias (15) & $-0.14^{* * *}$ & $-0.04 *$ & $-0.04 *$ & -0.01 & -0.02 & $-0.11^{* * *}$ & $-0.11^{* * *}$ & $-0.10^{* * *}$ & $-0.11^{* * *}$ & -0.01 & -0.01 & $-0.07^{* * *}$ & -0.02 & $0.18^{* * *}$ & 1 & & \\
\hline Momentum (16) & $-0.12^{* * *}$ & $-0.21 * * *$ & $-0.38 * * *$ & $0.33^{* * *}$ & $-0.17 * * *$ & $0.05^{* *}$ & $-0.06 * * *$ & $-0.04 *$ & $0.05^{* *}$ & $-0.07^{* * *}$ & $0.13^{* * *}$ & $-0.06^{* * *}$ & $-0.32^{* * *}$ & $-0.06^{* * *}$ & $-0.08 * * *$ & 1 & \\
\hline FX volatility (17) & $-0.08 * * *$ & $-0.24 * * *$ & $-0.22 * * *$ & $0.37^{* * * *}$ & $-0.09 * * *$ & $0.15^{* * *}$ & $-0.08 * * *$ & $-0.12 * * *$ & $-0.23 * * *$ & $-0.35^{* * * *}$ & $-0.09 * * *$ & $-0.28 * * *$ & $-0.41 * * *$ & $-0.17^{* * *}$ & $0.04 *$ & $0.09^{* * *}$ & 1 \\
\hline
\end{tabular}


Table 4: Location based FXD turnover regression

The dependent variable is Country allocations reflecting cross-country equity portfolio allocations $\left(w_{i j t}\right)$ of investors domiciled in source country $i$ into host country $j(i \neq j)$. The key independent variable $F X D L B$ present the share of location based daily average turnover of FXD in the world turnover for each host country. The controls in the first regression include the log value of the ICAPM benchmark and the three bilateral familiarity variables (Bilateral distance, Bilateral trade and Language). The second regression incrementally log of Stock market development/size and Stock market liquidity. The third regression further includes all other controls such as Capital controls, Macroeconomic policy risk, Investor protection, Diversification potential, Autohbias, Momentum, FX volatility, Spot turnover, Country fixed effects and Time fixed effects. All the controls are described in Table 3. For ease of comparability, all regression coefficients are interpreted as partial elasticity and are estimated using the GLS random effect panel data model. The $t$-statistics are in parentheses and use cluster robust standard errors correcting for within panel intra-cluster correlations. ${ }^{* *}, * *$ and $*$ indicate statistical significance levels at $1 \%, 5 \%$ and $10 \%$ respectively.

Information controls $\quad$ Information and stock $\quad$ All controls including only market development country and time

\begin{tabular}{|c|c|c|c|}
\hline & & controls & fixed effects \\
\hline FXDCB & $\begin{array}{c}0.125^{* * *} \\
(3.39)\end{array}$ & $\begin{array}{c}0.130^{* * *} \\
(3.40)\end{array}$ & $\begin{array}{c}0.520 * * * \\
(3.30)\end{array}$ \\
\hline ICAPM Benchmark & $\begin{array}{c}0.599 * * * \\
(5.41)\end{array}$ & $\begin{array}{c}0.568 * * * \\
(4.59)\end{array}$ & $\begin{array}{c}0.585^{* * *} * \\
(9.17)\end{array}$ \\
\hline Bilateral distance & $\begin{array}{c}-0.836^{* * * *} \\
(-10.68)\end{array}$ & $\begin{array}{c}-0.832 * * * \\
(-10.73)\end{array}$ & $\begin{array}{c}-0.495 * * * \\
(-5.04)\end{array}$ \\
\hline Bilateral trade & $\begin{array}{c}0.351 * * * \\
(7.22)\end{array}$ & $\begin{array}{c}0.364 * * * \\
(7.62)\end{array}$ & $\begin{array}{c}0.497 * * * \\
(9.05)\end{array}$ \\
\hline Common language dummy & $\begin{array}{c}0.869^{* * *} \\
(5.87)\end{array}$ & $\begin{array}{c}0.838^{* * *} \\
(6.31)\end{array}$ & $\begin{array}{l}0.595^{* * *} \\
(3.78)\end{array}$ \\
\hline Stock market size/development & & $\begin{array}{c}0.0765 * \\
(1.84)\end{array}$ & $\begin{array}{c}0.0804 \\
(0.82)\end{array}$ \\
\hline Market liquidity & & $\begin{array}{c}0.223 * * * \\
(4.29)\end{array}$ & $\begin{array}{c}0.136^{* * * *} \\
(4.18)\end{array}$ \\
\hline Capital controls & & & $\begin{array}{c}0.129^{* *} \\
(2.44)\end{array}$ \\
\hline Macroeconomic policy risk & & & $\begin{array}{l}-2.618 \\
(-1.45)\end{array}$ \\
\hline Investor protection & & & $\begin{array}{l}11.08^{*} \\
(1.73)\end{array}$ \\
\hline Diversification potential & & & $\begin{array}{l}-0.122 \\
(-0.49)\end{array}$ \\
\hline Autohbias & & & $\begin{array}{c}-0.265 * * * \\
(-3.45)\end{array}$ \\
\hline Momentum & & & $\begin{array}{c}-1.394 * * \\
(-2.46)\end{array}$ \\
\hline FX volatility & & & $\begin{array}{l}-0.909 \\
(-0.55)\end{array}$ \\
\hline Spot turnover & & & $\begin{array}{c}2.395 * * * \\
(2.98)\end{array}$ \\
\hline Country fixed effects & & & Yes \\
\hline Time fixed effects & & & Yes \\
\hline Constant & $\begin{array}{c}6.100 * * * \\
(12.86)\end{array}$ & $\begin{array}{c}5.793 * * * \\
(7.79)\end{array}$ & $\begin{array}{c}-0.0680 \\
(-0.06)\end{array}$ \\
\hline $\begin{array}{l}\text { Overall } \mathrm{R}^{2} \\
\text { Number of observations }\end{array}$ & $\begin{array}{l}0.475 \\
6714\end{array}$ & $\begin{array}{l}0.575 \\
6714\end{array}$ & $\begin{array}{l}0.631 \\
5348\end{array}$ \\
\hline
\end{tabular}


Table 5: Currency distribution based FXD turnover regression

The dependent variable is Country allocations reflecting cross-country equity portfolio allocations $\left(w_{i j t}\right)$ of investors domiciled in source country $i$ into host country $j(i \neq j)$. The key independent variable $F X D C B$ present the share of currency based daily average turnover of FXD in the world turnover for each host country. The controls in the first regression include the log value of the ICAPM benchmark and the three bilateral familiarity variables (Bilateral distance, Bilateral trade and Language). The second regression incrementally log of Stock market development/size and Stock market liquidity. The third regression further includes all other controls such as Capital controls, Macroeconomic policy risk, Investor protection, Diversification potential, Autohbias, Momentum, FX volatility, Spot turnover, Country fixed effects and Time fixed effects. All the controls are described in Table 3. For ease of comparability, all regression coefficients are interpreted as partial elasticity and are estimated using the GLS random effect panel data model. The $t$-statistics are in parentheses and use cluster robust standard errors correcting for within panel intra-cluster correlations. ${ }^{* *}, * *$ and $*$ indicate statistical significance levels at $1 \%, 5 \%$ and $10 \%$ respectively. Information controls Information and stock All controls including only market development country and time

\begin{tabular}{|c|c|c|c|}
\hline & & controls & fixed effects \\
\hline FXDCB & $\begin{array}{c}0.201 * * * \\
(4.33)\end{array}$ & $\begin{array}{c}0.211 * * * \\
(4.86)\end{array}$ & $\begin{array}{c}0.345 * * * \\
(4.64)\end{array}$ \\
\hline ICAPM Benchmark & $\begin{array}{c}0.649 * * * \\
(11.40)\end{array}$ & $\begin{array}{c}0.637 * * * \\
(8.30)\end{array}$ & $\begin{array}{c}0.644 * * * \\
(9.99)\end{array}$ \\
\hline Bilateral distance & $\begin{array}{c}-0.760 * * * \\
(-9.80)\end{array}$ & $\begin{array}{c}-0.761 * * * \\
(-9.93)\end{array}$ & $\begin{array}{c}-0.518^{* * *} \\
(-5.44)\end{array}$ \\
\hline Bilateral trade & $\begin{array}{c}0.357 * * * \\
(6.91)\end{array}$ & $\begin{array}{c}0.367 * * * \\
(7.15)\end{array}$ & $\begin{array}{c}0.421 * * * \\
(8.31)\end{array}$ \\
\hline Common language dummy & $\begin{array}{c}0.920 * * * \\
(5.37)\end{array}$ & $\begin{array}{c}0.899 * * * \\
(5.67)\end{array}$ & $\begin{array}{c}0.635 * * * \\
(3.96)\end{array}$ \\
\hline Stock market size/ development & & $\begin{array}{c}0.0500 \\
(1.61)\end{array}$ & $\begin{array}{l}0.0967 \\
(1.01)\end{array}$ \\
\hline Stock market liquidity & & $\begin{array}{c}0.577 * * * \\
(3.91)\end{array}$ & $\begin{array}{c}0.309 * * * \\
(3.46)\end{array}$ \\
\hline Capital controls & & & $\begin{array}{c}0.0584 * * \\
(2.40)\end{array}$ \\
\hline Macroeconomic policy risk & & & $\begin{array}{l}1.353 \\
(1.14)\end{array}$ \\
\hline Investor protection & & & $\begin{array}{l}-1.457 \\
(-0.27)\end{array}$ \\
\hline Diversification potential & & & $\begin{array}{l}0.202 \\
(0.85)\end{array}$ \\
\hline Autohbias & & & $\begin{array}{c}-0.312^{* * *} \\
(-3.48)\end{array}$ \\
\hline Momentum & & & $\begin{array}{l}-0.338 \\
(-0.81)\end{array}$ \\
\hline FX volatility & & & $\begin{array}{l}1.235 \\
(1.27)\end{array}$ \\
\hline Spot turnover & & & $\begin{array}{c}2.932 * * * \\
(5.27)\end{array}$ \\
\hline Country fixed effects & & & Yes \\
\hline Year fixed effects & & & Yes \\
\hline Constant & $\begin{array}{c}5.947 * * * \\
(12.97)\end{array}$ & $\begin{array}{c}6.023 * * * \\
(7.66)\end{array}$ & $\begin{array}{l}0.170 \\
(0.12)\end{array}$ \\
\hline $\begin{array}{l}\text { Overall } \mathrm{R}^{2} \\
\text { Number of observations }\end{array}$ & $\begin{array}{l}0.527 \\
4593\end{array}$ & $\begin{array}{l}0.628 \\
4593\end{array}$ & $\begin{array}{l}0.683 \\
3690\end{array}$ \\
\hline
\end{tabular}


Table 6: Bid-ask spread based regression

The dependent variable is Country allocations reflecting cross-country equity portfolio allocations ( $w_{i j t}$ ) of investors domiciled in source country $i$ into host country $j(i \neq j)$. The key independent variable $F X D S B$ is the yearly average bid-ask spread of the respective countries' currencies against the US dollar. The controls in the first regression include the log value of the ICAPM benchmark and the three bilateral familiarity variables (Bilateral distance, Bilateral trade and Language). The second regression incrementally log of Stock market development/size and Stock market liquidity. The third regression further includes all other controls such as Capital controls, Macroeconomic policy risk, Investor protection, Diversification potential, Autohbias, Momentum, FX volatility, Spot turnover, Country fixed effects and Time fixed effects. All the controls are described in Table 3. For ease of comparability, all regression coefficients are interpreted as partial elasticity and are estimated using the GLS random effect panel data model. The $t$-statistics are in parentheses and use cluster robust standard errors correcting for within panel intra-cluster correlations. ${ }^{* * *}, * *$ and $*$ indicate statistical significance levels at $1 \%, 5 \%$ and $10 \%$ respectively.

\begin{tabular}{|c|c|c|c|}
\hline & $\begin{array}{l}\text { Information controls } \\
\text { only }\end{array}$ & $\begin{array}{c}\text { Information and stock } \\
\text { market development } \\
\text { controls }\end{array}$ & $\begin{array}{l}\text { All controls including } \\
\text { country and time } \\
\text { fixed effects }\end{array}$ \\
\hline FXDSB & $\begin{array}{c}-0.111 * * \\
(-2.34)\end{array}$ & $\begin{array}{c}-0.101 * * \\
(-2.06)\end{array}$ & $\begin{array}{c}-0.326^{* *} \\
(-2.35)\end{array}$ \\
\hline ICAPM Benchmark & $\begin{array}{c}0.723 * * * \\
(16.80)\end{array}$ & $\begin{array}{c}0.680 * * * \\
(13.90)\end{array}$ & $\begin{array}{c}0.611 * * * \\
(11.35)\end{array}$ \\
\hline Bilateral distance & $\begin{array}{c}-0.917 * * * \\
(-13.39)\end{array}$ & $\begin{array}{c}-0.913 * * * \\
(-13.17)\end{array}$ & $\begin{array}{c}-0.483 * * * \\
(-4.52)\end{array}$ \\
\hline Bilateral trade & $\begin{array}{c}0.260 * * * \\
(5.38)\end{array}$ & $\begin{array}{c}0.265 * * * \\
(5.41)\end{array}$ & $\begin{array}{c}0.477 * * * \\
(7.59)\end{array}$ \\
\hline Common language dummy & $\begin{array}{c}0.981 * * * \\
(6.36)\end{array}$ & $\begin{array}{c}0.961 * * * \\
(6.37)\end{array}$ & $\begin{array}{c}0.484 * * * \\
(2.98)\end{array}$ \\
\hline Stock market size/development & & $\begin{array}{l}0.0636 \\
(1.57)\end{array}$ & $\begin{array}{l}0.158 * \\
(1.70)\end{array}$ \\
\hline Stock market liquidity & & $\begin{array}{c}0.920^{*} \\
(1.85)\end{array}$ & $\begin{array}{c}0.339 * * * \\
(3.49)\end{array}$ \\
\hline Capital controls & & & $\begin{array}{c}0.0188^{* *} \\
(2.41)\end{array}$ \\
\hline Macroeconomic policy risk & & & $\begin{array}{l}-0.212 \\
(-0.20)\end{array}$ \\
\hline Investor protection & & & $\begin{array}{l}8.850 \\
(1.64)\end{array}$ \\
\hline Diversification potential & & & $\begin{array}{c}-0.0655 \\
(-0.26)\end{array}$ \\
\hline Autohbias & & & $\begin{array}{c}-0.254 * * * \\
(-3.17)\end{array}$ \\
\hline Momentum & & & $\begin{array}{c}-0.675^{*} \\
(-1.80)\end{array}$ \\
\hline FX volatility & & & $\begin{array}{c}-1.850^{*} \\
(-1.65)\end{array}$ \\
\hline Spot turnover & & & $\begin{array}{l}2.229 * * * \\
(3.96)\end{array}$ \\
\hline Country fixed effects & & & Yes \\
\hline Year fixed effects & & & Yes \\
\hline Constant & $\begin{array}{c}5.797 * * * \\
(10.63)\end{array}$ & $\begin{array}{c}4.952 * * * \\
(8.60)\end{array}$ & $\begin{array}{l}-1.165 \\
(-0.89)\end{array}$ \\
\hline Overall $\mathrm{R}^{2}$ & 0.441 & 0.542 & 0.619 \\
\hline Number of observations & 15599 & 15599 & 4749 \\
\hline
\end{tabular}


Table 7: Reverse causality

The dependent variable in three regressions is the log value of equity portfolio country allocations $\left(w_{i j t}\right)$ of investors domiciled in country $i$ into country $j(i \neq j)$. The three key independent variables of interest are one period Lagged FXD Turnover measures, i.e. $F X D L B_{t-1}, F X D C B_{t-1}$ and $F X D S B_{t-1}$. The $F X D L B, F X D C B, F X D S B$ and all the control variables are described in Tables 3. For ease of comparability, all regression coefficients are interpreted as partial elasticity and are estimated using the GLS random effect panel data model. The $t$-statistics are in parentheses and use cluster robust standard errors correcting for within panel intra-cluster correlations. ${ }^{* *}, * *$ and $*$ indicate statistical significance levels at $1 \%$, $5 \%$ and $10 \%$ respectively.

\begin{tabular}{|c|c|c|c|}
\hline & FXDLB & FXDCB & FXDSB \\
\hline Lagged FXD liquidity & $\begin{array}{l}0.580 * * * \\
(3.53)\end{array}$ & $\begin{array}{l}0.291 * * * \\
(3.20)\end{array}$ & $\begin{array}{c}-0.321 * * * \\
(-2.56)\end{array}$ \\
\hline Benchmark & $\begin{array}{l}0.779 * * * \\
(8.40)\end{array}$ & $\begin{array}{c}0.697 * * * \\
(10.66)\end{array}$ & $\begin{array}{c}0.734 * * * \\
(11.91)\end{array}$ \\
\hline Bilateral distance & $\begin{array}{c}-0.556 * * * \\
(-5.22)\end{array}$ & $\begin{array}{c}-0.547 * * * \\
(-5.60)\end{array}$ & $\begin{array}{c}-0.547 * * * \\
(-5.28)\end{array}$ \\
\hline Bilateral trade & $\begin{array}{l}0.339 * * * \\
(4.58)\end{array}$ & $\begin{array}{c}0.431 * * * \\
(6.29)\end{array}$ & $\begin{array}{c}0.397 * * * \\
(5.39)\end{array}$ \\
\hline Common language dummy & $\begin{array}{l}0.708 * * * \\
(3.88)\end{array}$ & $\begin{array}{l}0.579 * * * \\
(3.63)\end{array}$ & $\begin{array}{l}0.442 * * * \\
(2.72)\end{array}$ \\
\hline Stock market size/development & $\begin{array}{c}0.0393 \\
(1.38)\end{array}$ & $\begin{array}{l}0.0204 * * \\
(2.19)\end{array}$ & $\begin{array}{c}0.0885^{* *} \\
(1.98)\end{array}$ \\
\hline Stock market liquidity & $\begin{array}{l}0.0220 * * * \\
(3.33)\end{array}$ & $\begin{array}{l}0.0569 * * * \\
(3.66)\end{array}$ & $\begin{array}{l}0.0264 * * * \\
(3.04)\end{array}$ \\
\hline Capital controls & $\begin{array}{c}0.0696^{* *} \\
(2.19)\end{array}$ & $\begin{array}{l}0.177^{* *} \\
(2.12)\end{array}$ & $\begin{array}{l}0.0501 * * \\
(2.31)\end{array}$ \\
\hline Macroeconomic policy risk & $\begin{array}{l}0.856 \\
(0.65)\end{array}$ & $\begin{array}{l}-2.934 \\
(-1.57)\end{array}$ & $\begin{array}{l}-0.290 \\
(-0.37)\end{array}$ \\
\hline Investor protection & $\begin{array}{l}-4.022 \\
(-0.52)\end{array}$ & $\begin{array}{l}12.33 \\
(1.49)\end{array}$ & $\begin{array}{l}8.521 \\
(1.47)\end{array}$ \\
\hline Diversification potential & $\begin{array}{l}0.323 \\
(1.25)\end{array}$ & $\begin{array}{l}-0.182 \\
(-0.72)\end{array}$ & $\begin{array}{c}-0.0867 \\
(-0.33)\end{array}$ \\
\hline Autohbias & $\begin{array}{c}-0.273 * * * \\
(-3.16)\end{array}$ & $\begin{array}{c}-0.237 * * * \\
(-2.96)\end{array}$ & $\begin{array}{c}-0.254 * * * \\
(-3.22)\end{array}$ \\
\hline Momentum & $\begin{array}{l}-0.513 \\
(-0.87)\end{array}$ & $\begin{array}{c}-1.477 * * \\
(-2.03)\end{array}$ & $\begin{array}{c}-0.776^{*} \\
(-1.71)\end{array}$ \\
\hline FX volatility & $\begin{array}{l}-0.651 \\
(-0.39)\end{array}$ & $\begin{array}{l}-2.553 \\
(-1.47)\end{array}$ & $\begin{array}{l}-0.446 \\
(-0.31)\end{array}$ \\
\hline Spot turnover & $\begin{array}{c}2.604 * * * \\
(5.90)\end{array}$ & $\begin{array}{c}1.815^{* * *} \\
(2.67)\end{array}$ & $\begin{array}{c}1.774 * * * \\
(3.68)\end{array}$ \\
\hline Country fixed effects & & & Yes \\
\hline Year fixed effects & & & Yes \\
\hline Constant & $\begin{array}{l}0.580 \\
(0.40)\end{array}$ & $\begin{array}{l}0.800 \\
(0.72)\end{array}$ & $\begin{array}{l}-0.168 \\
(-0.13)\end{array}$ \\
\hline $\begin{array}{l}\text { Overall } \mathrm{R}^{2} \\
\text { Number of observations }\end{array}$ & $\begin{array}{l}0.684 \\
2782\end{array}$ & $\begin{array}{l}0.633 \\
4061\end{array}$ & $\begin{array}{l}0.625 \\
3744\end{array}$ \\
\hline
\end{tabular}


Table 8: Regressions excluding major financial centres

The dependent variable in all three regressions is the log value of equity portfolio country allocations $\left(w_{i j t}\right)$ of investors domiciled in country $i$ into country $j$. The three key independent variables of interest are FXD Liquidity measures, i.e. $F X D L B, F X D C B$ and FXDSB. The FXDLB, FXDCB, FXDSB and all the controls are described Table 3. Compared to the full sample, the regression excludes major financial centres such as the United Kingdom, the United States, Japan, Singapore, Hong Kong and the Netherlands from the sample. For ease of comparability, all regression coefficients are interpreted as partial elasticity and are estimated using the GLS random effect panel data model. The $t$-statistics are in parentheses and use cluster robust standard errors correcting for within panel intra-cluster correlations. $* * *$, ** and * indicate statistical significance levels at $1 \%, 5 \%$ and $10 \%$ respectively.

\begin{tabular}{|c|c|c|c|}
\hline & FXDLB & FXDCB & FXDSB \\
\hline FXD Liquidity & $\begin{array}{c}0.144 * * \\
(2.57)\end{array}$ & $\begin{array}{c}0.215^{* * *} \\
(3.05)\end{array}$ & $\begin{array}{c}-0.113 * * * \\
(-3.80)\end{array}$ \\
\hline Benchmark & $\begin{array}{c}0.727 * * * \\
(9.39)\end{array}$ & $\begin{array}{c}0.656^{* * *} \\
(7.41)\end{array}$ & $\begin{array}{c}0.652 * * * \\
(8.96)\end{array}$ \\
\hline Bilateral distance & $\begin{array}{c}-0.544 * * * \\
(-4.88)\end{array}$ & $\begin{array}{c}-0.530 * * * \\
(-4.84)\end{array}$ & $\begin{array}{c}-0.500 * * * \\
(-4.01)\end{array}$ \\
\hline Bilateral trade & $\begin{array}{c}0.421 * * * \\
(6.86)\end{array}$ & $\begin{array}{c}0.473 * * * \\
(7.06)\end{array}$ & $\begin{array}{c}0.461 * * * \\
(6.41)\end{array}$ \\
\hline Common language dummy & $\begin{array}{c}0.651 * * * \\
(3.54)\end{array}$ & $\begin{array}{c}0.681 * * * \\
(3.81)\end{array}$ & $\begin{array}{c}0.538 * * * \\
(2.96)\end{array}$ \\
\hline Stock market size/development & $\begin{array}{l}0.127 \\
(1.35)\end{array}$ & $\begin{array}{c}0.0167 * * \\
(2.01)\end{array}$ & $\begin{array}{c}0.103^{*} \\
(1.68)\end{array}$ \\
\hline Stock market liquidity & $\begin{array}{c}0.077 * * \\
(2.15)\end{array}$ & $\begin{array}{c}0.098 * * \\
(2.01)\end{array}$ & $\begin{array}{c}0.0711 * * \\
(2.08)\end{array}$ \\
\hline Capital controls & $\begin{array}{c}0.0604^{* *} \\
(2.14)\end{array}$ & $\begin{array}{l}0.162 \\
(1.55)\end{array}$ & $\begin{array}{c}0.0272 \\
(1.57)\end{array}$ \\
\hline Macroeconomic policy risk & $\begin{array}{l}0.518 \\
(0.41)\end{array}$ & $\begin{array}{c}-2.813^{*} \\
(-1.69)\end{array}$ & $\begin{array}{l}-0.842 \\
(-0.70)\end{array}$ \\
\hline Investor protection & $\begin{array}{l}-2.153 \\
(-0.39)\end{array}$ & $\begin{array}{l}9.324 \\
(1.48)\end{array}$ & $\begin{array}{l}5.726 \\
(1.03)\end{array}$ \\
\hline Diversification potential & $\begin{array}{l}0.249 \\
(0.88)\end{array}$ & $\begin{array}{c}-0.0992 \\
(-0.35)\end{array}$ & $\begin{array}{l}0.126 \\
(0.40)\end{array}$ \\
\hline Autohbias & $\begin{array}{c}-0.308 * * * \\
(-2.91)\end{array}$ & $\begin{array}{c}-0.295 * * * \\
(-3.32)\end{array}$ & $\begin{array}{c}-0.243 * * * \\
(-2.73)\end{array}$ \\
\hline Momentum & $\begin{array}{c}-0.774 * * \\
(-2.21)\end{array}$ & $\begin{array}{c}-1.659 * * * \\
(-2.82)\end{array}$ & $\begin{array}{c}-0.753^{*} \\
(-1.83)\end{array}$ \\
\hline FX volatility & $\begin{array}{c}-1.909 * * \\
(-2.14)\end{array}$ & $\begin{array}{l}-0.192 \\
(-0.11)\end{array}$ & $\begin{array}{c}-2.326^{*} \\
(-1.75)\end{array}$ \\
\hline Spot turnover & $\begin{array}{c}2.554 * * * \\
(4.41)\end{array}$ & $\begin{array}{c}2.512 * * * \\
(3.40)\end{array}$ & $\begin{array}{c}2.191 * * * \\
(4.17)\end{array}$ \\
\hline Country fixed effects & & & Yes \\
\hline Year fixed effects & & & Yes \\
\hline Constant & $\begin{array}{l}1.913 \\
(1.17) \\
\end{array}$ & $\begin{array}{l}0.578 \\
(0.42) \\
\end{array}$ & $\begin{array}{l}-0.226 \\
(-0.14) \\
\end{array}$ \\
\hline Overall $\mathrm{R}^{2}$ & 0.680 & 0.628 & 0.609 \\
\hline Number of observations & 2985 & 4373 & 3821 \\
\hline
\end{tabular}


Table 9: Regressions with float adjusted benchmark

The dependent variable in three regressions is the log value of equity portfolio country allocations $\left(w_{i j t}\right)$ of investors domiciled in country $i$ into country $j$. The three key independent variables of interest are FXD Liquidity measures, i.e. $F X D L B, F X D C B$ and FXDSB. The FXDLB, FXDCB, FXDSB and all the controls are described Table 3 . In all three regressions the benchmark used (Float adjusted benchmark) is constructed using float adjusted market capitalization. For ease of comparability, all regression coefficients are interpreted as partial elasticity and are estimated using the GLS random effect panel data model. The $t$-statistics are in parentheses and use cluster robust standard errors correcting for within panel intra-cluster correlations. $* * *, * *$ and $*$ indicate statistical significance levels at $1 \%, 5 \%$ and $10 \%$ respectively.

\begin{tabular}{|c|c|c|c|}
\hline & FXDLB & FXDCB & FXDSB \\
\hline FXD Liquidity & $\begin{array}{c}0.137 * * \\
(2.11)\end{array}$ & $\begin{array}{l}0.0809 * * \\
(2.20)\end{array}$ & $\begin{array}{c}-0.130 * * \\
(-2.31)\end{array}$ \\
\hline Float adjusted benchmark & $\begin{array}{l}0.554 * * * \\
(7.42)\end{array}$ & $\begin{array}{c}0.575 * * * \\
(10.96)\end{array}$ & $\begin{array}{c}0.552 * * * \\
(10.14)\end{array}$ \\
\hline Bilateral distance & $\begin{array}{c}-0.443 * * * \\
(-4.92)\end{array}$ & $\begin{array}{c}-0.483 * * * \\
(-5.50)\end{array}$ & $\begin{array}{c}-0.445 * * * \\
(-4.68)\end{array}$ \\
\hline Bilateral trade & $\begin{array}{c}0.472 * * * \\
(10.14)\end{array}$ & $\begin{array}{c}0.497 * * * \\
(10.23)\end{array}$ & $\begin{array}{c}0.503 * * * \\
(9.76)\end{array}$ \\
\hline Common language dummy & $\begin{array}{c}0.587 * * * \\
(3.96)\end{array}$ & $\begin{array}{c}0.578 * * * \\
(3.65)\end{array}$ & $\begin{array}{l}0.463 * * * \\
(2.92)\end{array}$ \\
\hline Stock market size/development & $\begin{array}{l}0.0417 \\
(1.52)\end{array}$ & $\begin{array}{c}0.0780^{*} \\
(1.80)\end{array}$ & $\begin{array}{c}0.172 * * \\
(2.03)\end{array}$ \\
\hline Stock market liquidity & $\begin{array}{c}0.223 * * * \\
(3.39)\end{array}$ & $\begin{array}{l}0.316 * * * \\
(3.04)\end{array}$ & $\begin{array}{c}0.267 * * * \\
(3.44)\end{array}$ \\
\hline Capital controls & $\begin{array}{c}0.0578 \\
(1.46)\end{array}$ & $\begin{array}{c}0.126 * * \\
(2.19)\end{array}$ & $\begin{array}{c}0.0197 \\
(0.44)\end{array}$ \\
\hline Macroeconomic policy risk & $\begin{array}{l}1.026 \\
(0.87)\end{array}$ & $\begin{array}{l}-2.702 \\
(-1.45)\end{array}$ & $\begin{array}{l}-0.312 \\
(-0.27)\end{array}$ \\
\hline Investor protection & $\begin{array}{l}-1.723 \\
(-0.29)\end{array}$ & $\begin{array}{l}8.939 \\
(1.44)\end{array}$ & $\begin{array}{l}6.569 \\
(1.22)\end{array}$ \\
\hline Diversification potential & $\begin{array}{l}0.191 \\
(0.79)\end{array}$ & $\begin{array}{l}-0.154 \\
(-0.62)\end{array}$ & $\begin{array}{c}-0.0934 \\
(-0.37)\end{array}$ \\
\hline Autohbias & $\begin{array}{c}-0.312 * * * \\
(-3.51)\end{array}$ & $\begin{array}{c}-0.264 * * * \\
(-3.44)\end{array}$ & $\begin{array}{c}-0.253 * * * \\
(-3.19)\end{array}$ \\
\hline Momentum & $\begin{array}{l}-0.144 \\
(-0.38)\end{array}$ & $\begin{array}{c}-1.261 * * \\
(-2.29)\end{array}$ & $\begin{array}{l}-0.531 \\
(-1.51)\end{array}$ \\
\hline FX volatility & $\begin{array}{l}-1.217 \\
(-1.26)\end{array}$ & $\begin{array}{l}-0.431 \\
(-0.27)\end{array}$ & $\begin{array}{c}-2.179 * * \\
(-2.09)\end{array}$ \\
\hline Spot turnover & $\begin{array}{c}2.564 * * * \\
(4.21)\end{array}$ & $\begin{array}{c}1.916^{* *} \\
(2.21)\end{array}$ & $\begin{array}{c}1.729 * * * \\
(2.97)\end{array}$ \\
\hline Country fixed effects & & & Yes \\
\hline Year fixed effects & & & Yes \\
\hline Constant & $\begin{array}{l}-0.548 \\
(-0.43) \\
\end{array}$ & $\begin{array}{l}0.117 \\
(0.11) \\
\end{array}$ & $\begin{array}{l}-1.351 \\
(-1.04) \\
\end{array}$ \\
\hline $\begin{array}{l}\text { Overall } \mathrm{R}^{2} \\
\text { Number of observations }\end{array}$ & $\begin{array}{l}0.680 \\
3690\end{array}$ & $\begin{array}{l}0.637 \\
5348\end{array}$ & $\begin{array}{l}0.618 \\
4749\end{array}$ \\
\hline
\end{tabular}


Table 10: Regressions with an alternative proxy of FXD Turnover

The dependent variable in the regression is the log value of equity portfolio country allocations $\left(w_{i j t}\right)$ of investors domiciled in country $i$ into country $j$. The key independent variable of interest is Alternative FXD Turnover Measure, which is the total daily average of all $F X D$ and spot transactions scaled by respective country's equity market capitalization (MCap). All the controls are described Table 3. For ease of comparability, all regression coefficients are interpreted as partial elasticity and are estimated using the GLS random effect panel data model. The $t$-statistics are in parentheses and use cluster robust standard errors correcting for within panel intra-cluster correlations. ${ }^{* * *},{ }^{* *}$ and $*$ indicate statistical significance levels at $1 \%, 5 \%$ and $10 \%$ respectively.

\begin{tabular}{|c|c|}
\hline & Total FX Turnover to MCap \\
\hline Alternative FXD Turnover Measure & $\begin{array}{l}0.3571^{* *} \\
(2.44)\end{array}$ \\
\hline ICAMP Benchmark & $\begin{array}{c}0.652 * * * \\
(10.18)\end{array}$ \\
\hline Bilateral distance & $\begin{array}{c}-0.527 * * * \\
(-5.00)\end{array}$ \\
\hline Bilateral trade & $\begin{array}{c}0.473 * * * \\
(8.05)\end{array}$ \\
\hline Common language dummy & $\begin{array}{c}0.581 * * * \\
(3.72)\end{array}$ \\
\hline Stock market size/development & $\begin{array}{c}0.0514 \\
(1.51)\end{array}$ \\
\hline Stock market liquidity & $\begin{array}{c}0.217 * * \\
(2.10)\end{array}$ \\
\hline Capital controls & $\begin{array}{c}0.136^{* *} \\
(2.11)\end{array}$ \\
\hline Macroeconomic policy risk & $\begin{array}{l}-2.723 \\
(-1.54)\end{array}$ \\
\hline Investor protection & $\begin{array}{l}9.913 \\
(1.61)\end{array}$ \\
\hline Diversification potential & $\begin{array}{l}-0.124 \\
(-0.49)\end{array}$ \\
\hline Autohbias & $\begin{array}{c}-0.269 * * * \\
(-3.48)\end{array}$ \\
\hline Momentum & $\begin{array}{c}-1.380 * * \\
(-2.57)\end{array}$ \\
\hline FX volatility & $\begin{array}{l}-0.401 \\
(-0.32)\end{array}$ \\
\hline Spot turnover & $\begin{array}{c}1.990 * * \\
(2.07)\end{array}$ \\
\hline Country fixed effects & Yes \\
\hline Year Fixed effects & Yes \\
\hline Constant & $\begin{array}{l}0.319 \\
(0.24)\end{array}$ \\
\hline $\begin{array}{l}\text { Overall } \mathrm{R}^{2} \\
\text { Number of observations }\end{array}$ & $\begin{array}{l}0.632 \\
5396\end{array}$ \\
\hline
\end{tabular}

